\title{
Sanctuary Cities: A Study in Modern NULLIFICATION?
}

\section{Lorraine Marie A. Simonis*}

\begin{abstract}
Since Donald Trump's election as President of the United States, the sanctuary movement has gained prominence as a form of resistance to federal immigration policy. Sanctuary cities and states have attempted to frustrate the Trump administration's immigration agenda by refusing to cooperate with Immigration and Customs Enforcement's (ICE's) efforts to remove aliens illegally residing in the United States. Academics, pundits and politicians have compared this resistance and non-cooperation to "nullification," a doctrine typically associated with the South Carolina Nullification Crisis of the 1830s and the Virginia and Kentucky Resolutions of 1798 .

This article rejects comparisons between the sanctuary movement and nullification as false equivalencies and explains why the sanctuary movement is not a form of modern nullification. Rather, it suggests the movement is better understood as being similar to "interposition"- a doctrine related to, but distinct from, nullification. In doing so, this paper will clarify the meaning of nullification and interposition by analyzing the developments of these doctrines. Part 1 of this article discusses the historical, theoretical and practical aspects of South Carolina-style nullification, and compares these to that of the sanctuary movement. Part 2 explores the development of nullification and interposition more broadly, with a particular focus on the Virginia and Kentucky Resolutions of 1798. Finally, Part 3 directly compares the sanctuary movement, nullification and interposition, and it connects the movement to the "anticommandeering" doctrine articulated by the Supreme Court in the 1990s.
\end{abstract}

\section{KEYWORDS}

Nullification, Interposition, Sanctuary Cities, Virginia and Kentucky Resolutions, Anti-commandeering

\section{CONTENTS}

INTRODUCTION ......................................................................... 39

I. Calhoun and Sanctuary Cities .............................................. 42

A. The South Carolina Nullification Crisis.......................................... 43

* Graduate, University of Virginia School of Law; Member, Pennsylvania State Bar. Many thanks to Professor Charles Barzun, without whose invaluable encouragement and guidance this article likely never would have been written - let alone published. Thanks to Professor Bill Connelly for his research suggestions. Thanks to Jennifer Popp, Neal Modi and Dillon Mahoney for reading through my drafts and offering helpful comments. And, thanks to authors Bill Watkins and Tom Woods for answering my emails. 
B. Calhoun and the Sanctuary Movement ........................................... 46

II. JefFerson, Madison and the SAnctuary Movement ....................... 47

A. Nullification and Interposition: Common Origins ........................ 47

B. Nullification: Meanings and Application ...................................... 52

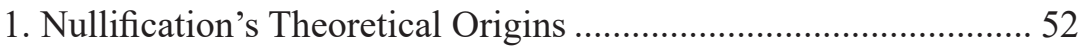

2. Nullification's Textual Basis .......................................................... 54

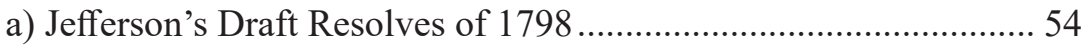

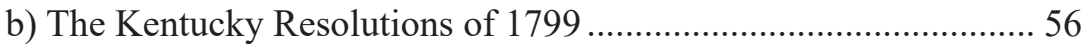

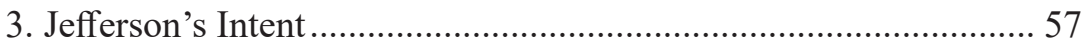

4. The Kentucky Legislature's Influence and Intent ...........................59

5. Contemporary Reception of the Kentucky Resolutions ................. 61

6. Jefferson, the Kentucky Resolutions and the Sanctuary

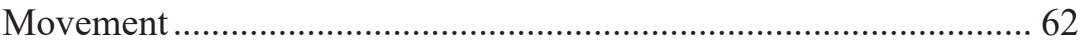

C. Interposition: Meanings and Application ......................................... 64

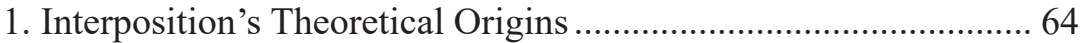

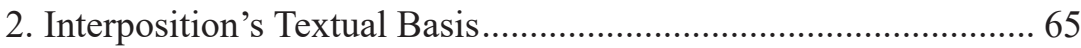

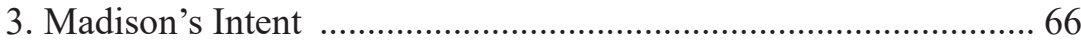

4. The Virginia Legislature's Influence and Intent............................... 70

5. Contemporary Reception of the Virginia Resolutions ................... 73

6. Applications of the Virginia Resolutions ........................................ 75

7. Madison, Interposition and the Sanctuary Movement................... 79

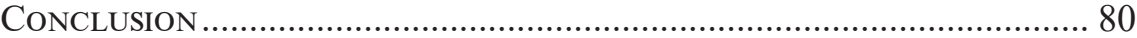




\section{INTRODUCTION}

What did South Carolinian John C. Calhoun (1782-1850) and San Francisco mayor Ed Lee (1952-2017) have in common? Both, apparently, adhered to the "discredited" doctrine of nullification.

As United States President Donald Trump has initiated his promised crackdown on illegal immigration, localities across the America have attempted to frustrate his efforts through a combination of advocacy, activism and non-cooperation. Broadly speaking, these so-called "sanctuary cities"2_-which actually include not just cities, but also states and counties - have limited local cooperation with federal immigration officials, particularly with regards to deportations. ${ }^{3}$

Because most U.S. jails are operated at the local level, ICE (Immigration and Customs Enforcement) relies on cities, counties and states to assist in its operations. After a person is arrested, he or she will typically be brought to a local jail. ${ }^{4}$ In jail, that person will be fingerprinted, and those fingerprints will be shared with the FBI, who will then share the prints with ICE. ${ }^{5}$ If ICE determines the person is undocumented, it will submit a "detainer request"-i.e. a request to detain the person in jail while ICE obtains permission to initiate deportation proceedings. ${ }^{6}$ In sanctuary cities, local law enforcement typically has a policy of refusing these detainer requests, either routinely or selectively. ${ }^{7}$

Trump's allies and sympathizers have been particularly critical of the sanctuary movement. Both before and after the 2017 Presidential election, Trump and his surrogates consistently emphasized the danger posed by sanctuary cities and illegal immigrants. From a legal-historical perspective, the comparison of sanctuary cities to nullification - a doctrine holding that states may invalidate federal law - has been a particularly interesting line of attack. In an attempt to undermine the sanctuary movement's legality, certain commentators and scholars have compared sanctuary cities' non-cooperation with federal officials to nullification, as well as to secession and Civil War. Such comparisons have been made by academics and pundits alike, with varying levels of sophistication.

In a March 2018 speech to California law enforcement, for example, thenUnited States Attorney General Jeff Sessions compared California's sanctuary

1 Christian G. Fritz, Interposition: An Overlooked Tool of American Constitutionalism, in UNiON \& StaTeS' Rights: A History and InTERPRETATION OF INTERPOSITION, NUllification, and Secession 150 Years After Sumter (henceforth Union \& States' Rights) 165, 165 (Neil H. Cogan, ed. 2014).

2 Some cities have preferred to term themselves "welcoming cities" rather than "sanctuary cities," but I will be using the term "sanctuary city" for clarity and consistency.

3 Jasmine C. Lee, Rudy Omri \& Julia Preston, What Are Sanctuary Cities?, N. Y. Times (Feb. 6, 2017), https://www.nytimes.com/interactive/2016/09/02/us/sanctuary-cities.html.

4 Darla Cameron, How Sanctuary Cities Work and How Trump's Blocked Executive Order Could Have Affected Them, WASH. Post (Nov. 21, 2017), https://www.washingtonpost.com/ graphics/national/sanctuary-cities/.

Id.

$I d$.

Id. An example of selective refusal would be refusing to honor detainer requests for persons with clean criminal records. 
policy to nullification. "There is no nullification," Sessions concluded; "any doubters" could "go to Gettysburg, to the tombstones of John C. Calhoun and Abraham Lincoln." Similarly, radio personality Mark Levin equated San Francisco with Kentucky county clerk Kim Davis — of "no marriage licenses for gay couples" fame-before declaring that sanctuary cities and states are actually "confederate cities and confederate states because they obviously believe in a confederation of nullifying states and cities against the federal union."10 "Didn't we fight a Civil War over this, ladies and gentlemen?," Levin incredulously asked his audience. Historian Victor David Hanson of Stanford University's Hoover Institution similarly raised the specter of Confederacy by linking supporters of sanctuary cities to "the illiberal pedigree of federal nullification, which was at the heart of the Confederate secessionist movement." 11 None other than John C. Calhoun, he declared, is "the spiritual godfather of sanctuary cities." 12 Not to be outdone, syndicated columnist Charles Krauthammer claimed that "these liberals, who want to do the sanctuary cities are speaking the language of the southern segregationists. The language of nullification and interposition, which incidentally, was the language of the Confederates." 13 Somewhat more reservedly, Seth Lipsky of the New York Post posed, "Is our country headed for a new nullification crisis?," presumably in reference to South Carolina's disagreements with the federal government during the 1830s. Yet Lipsky also mentioned Virginia and Kentucky's Resolutions of 1798 and states' resistance to the Fugitive Slave Act as instances of nullification. ${ }^{14}$ Political strategist Karl Rove similarly branded Trump's opponents as " $21^{\text {st }}$ century nullifiers" in the mold of Calhoun. ${ }^{15}$ Meanwhile, legal writer Thomas Ascik asserted that "sanctuary cities use legal tactics from the Civil War South," before stating, a line later, that nullification actually preceded the war. ${ }^{16}$

8 Stephan Dinan, Sessions Likens California Sanctuary Laws to Slave-State Nullification, WaSH. Times (March 7, 2018), https://www.washingtontimes.com/news/2018/mar/7/ sessions-calif-sanctuary-slave-state-nullification/. Sessions resigned as Attorney General in November 2018.

$9 \quad$ Id.

10 Michael Morris, Levin on Sanctuary Cities: They Are Nullifying Federal Law...Didn't We Fight Civil War Over This?, Cns News (Dec. 1, 2016), https://www.cnsnews.com/blog/ michael-morris/levin-sanctuary-cities-nullification-federal-law-didnt-we-fight-civil-warover.

11 Victor David Hansen, Are Sanctuary Cities the New Confederates?, Nat. Rev. (Oct. 15 , 2015), http://www.nationalreview.com/article/425564/are-sanctuary-cities-newconfederates-victor-davis-hanson.

12 Id.

13 Ian Hanchett, Krauthammer: Sanctuary Cities Speaking the Language of Southern Segregationists, BreItBART News (Dec. 5, 2016), http://www.breitbart.com/ video/2016/12/05/krauthammer-sanctuary-cities-speaking-the-language-of-the-southernsegregationists/.

14 Seth Lipsky, Sanctuary Cities Must Still Obey the Constitution, N. Y. Post (Jan. 25, 2017), http://nypost.com/2017/01/25/sanctuary-cities-must-still-obey-the-constitution/.

15 Karl Rove, Trump and the 21st Century Nullifiers, WALL St. J. (Feb. 8, 2017), https://www. wsj.com/articles/trump-and-the-21st-century-nullifiers-1486597277.

16 Thomas Asick, Sanctuary Cities Use Legal Tactics From the Civil War South, THE FeDERALIST (Feb. 27, 2017), https://thefederalist.com/2017/02/27/leaders-sanctuary-citiesusing-tactics-civil-war-south/. 
Not all commentators, however, have accepted these comparisons between sanctuary cities and the (pre-)Civil War South. Unsurprisingly, perhaps, those sympathetic to the sanctuary movement have preferred dwelling on the supposed similarities between local resistance to immigration policy and local resistance to the Fugitive Slave Act, rather than on parallels to Calhoun or confederacy. Law professor Christopher Lasch of the University of Denver called those communities which resisted enforcement of the Fugitive Slave Act "a more meaningful historical analogue" to the sanctuary city situation. ${ }^{17}$ "Sanctuary cities," he explained, "share with their abolitionist forebears a deep moral commitment to liberty and equality. And, when it comes to legal theory, sanctuary policy is rooted not in the nullification theory popular in the slaveholding South, but rather in the Tenth Amendment's prohibition on federal "commandeering' of local government."18 Somewhat more pragmatically, University of Florida history professor Sean Trainor compared the sanctuary city movement and Northern opposition to the Fugitive Slave Act by arguing that Trump's opposition "would also, like the $1850 \mathrm{law}^{19}$, create common ground between activists on the issue and those who are merely opponents of federal encroachment." 20

So which is it? Are we in midst of a new nullification crisis, as Rove and the like suggest? Or, per Lasch, are comparisons between contemporary progressive enclaves and the antebellum South wholly inappropriate? Or yet still, have some scholars and commentators on all sides misunderstood the nature of nullification, and its relationship to civil liberties and local governance?

$* * *$

Though no federal court today is likely to recognize nullification as a legitimate constitutional doctrine, the concept enjoyed a modest modern renaissance beginning during the Obama administration. State legislators across the country have appealed to nullification to resist federal involvement in spheres as diverse as health insurance ${ }^{21}$ and gun control. ${ }^{22}$ As a result, legal scholars of such renown as the University of Texas's Sanford Levinson have been prompted to reassess the doctrine's modern relevance-albeit skeptically and often unfavorably. ${ }^{23}$

17 Christopher Lasch, Resistance to the Fugitive Slave Act Gives Sanctuary Cities a Model for Resistance to Trump, RAw STORY (Feb. 22, 2017), https://www.rawstory.com/2017/02/ resistance-to-the-fugitive-slave-act-gives-sanctuary-cities-a-model-for-resistance-totrump/.

18 Id.

19 By "the 1850 law," the author is referring to the Fugitive Slave Act.

20 Sean Trainor, What the Fugitive Slave Act Can Teach Us About Sanctuary Cities, Time (Feb. 7, 2017), http://time.com/4659391/sanctuary-cities-fugitive-slave-act/.

21 See e.g. Richard Cauchi, State Laws and Actions Challenging Certain Health Reforms, National Conference of State Legislatures (March 25, 2017), http://www.ncsl.org/ research/health/state-laws-and-actions-challenging-ppaca.aspx.

22 See e.g. Justine McDaniel et al., In States, a Legislative Rush to Nullify Federal Gun Laws, WASH. Post (Aug. 29, 2014), https://www.washingtonpost.com/blogs/ govbeat/wp/2014/08/29/in-states-a-legislative-rush-to-nullify-federal-gun-laws/?utm term=.777a7c7203f9; Sanford Levinson, The Twenty-First Century Rediscovery of Nullification and Secession in American Political Rhetoric: Frivolousness Incarnate of Serious Arguments to Be Wrestled With?, 67 ARK. L. Rev. 17, 18-19 (2014) (referring to Missouri and Kansas efforts to nullify federal gun control laws).

23 Levinson, supra note 22, at 27-28. 
Nevertheless, nullification and its related doctrine of interposition remain poorly defined-complicating and confusing comparisons of nullification to modern phenomena such as the sanctuary movement.

The emergence of these comparisons between the sanctuary movement and nullification offers an opportunity to re-examine and define nullification and the related doctrine of interposition. While such re-examination and definition may eventually be extended to examining phenomena other than the sanctuary movement, clarifying the relationship between nullification and the sanctuary movement remains especially relevant. Precisely because most academics and judges have rejected nullification are the nullifying charges leveled against the movement so serious.

Despite some superficial similarities, however, the sanctuary movement is not an example of modern nullification. The sanctuary movement has adopted neither the constitutional arguments nor the political mechanisms of $19^{\text {th }}$ century South Carolina. ${ }^{24}$ Unlike the sanctuary movement, nullification relies on compact theory - the idea that the federal government is a creature of the still-sovereign states - and operates through state conventions. Nevertheless, the sanctuary movement arguably resembles nullification's related doctrine of interposition. Like $19^{\text {th }}$ century advocates of interposition, today's sanctuary movement appeals to the importance of checks and balance and individual liberties to justify its opposition to federal law. Moreover, interposition is compatible with the contemporary and well-established anti-commandeering doctrine, which limits federal power over state officials.

This paper clarifies the meaning of nullification and interposition by analyzing the developments of these doctrines. It will also evaluate comparisons between the sanctuary movement, nullification, and interposition. Part 1 of this paper discusses the historical, theoretical and practical aspects of South Carolina-style nullification, and compares these to that of the sanctuary movement. Part 2 explores the development of nullification and interposition more broadly, with a particular focus on the Virginia and Kentucky Resolutions of 1798. Finally, it concludes that the sanctuary movement is not an instance of modern nullification-even excluding the South Carolina example. It will also suggest that the sanctuary movement is more compatible with the related concept of interposition.

\section{CAlhoun and SAnctuary Cities}

Though the idea of nullification was developed by Thomas Jefferson in the 1790s, the doctrine is today primarily associated with John C. Calhoun and the South Carolina Nullification Crisis of the 1830s. If it is Calhoun rather than Jefferson who commentators claim as the "spiritual godfather" of the sanctuary movement, it is in part because the Crisis translated constitutional theory into concrete action. The historical record allows us to understand not only why Calhoun and the South Carolina nullifiers thought nullification legitimate and necessary, but also what nullification looked like in practice; we can thus compare their and the sanctuary

24 For a condensed version of this argument, see William J. Watkins, Jr., Sanctuary Cities Are Not the New Nullification Crisis, Law360 (May 23, 2017), https://www.law360.com/ articles/927395/sanctuary-cities-are-not-the-new-nullification-crisis. 
movement's motivations and strategies. Such a comparison readily reveals that the South Carolina nullifiers and the sanctuary movement have little in common beyond the fact that both involved local disagreement with federal policy.

\section{A. The South Carolina NullifiCation CRISIS}

The Nullification Crisis began as a debate over trade policy. After the War of 1812, the federal government passed a series of tariffs to protect and strengthen New England's fledgling industry. New England's industry prospered, but as a result, the price of foreign goods on the American market also increased. Initially, Americans across the country - Calhoun included - supported the measure. ${ }^{25}$ Over the years, however, as the tariff not only persisted but increased, Southerners started to resent its operation. While the South was a primarily agricultural region dependent on the production of raw materials, the North was a primarily industrial region dependent on the manufacturing of goods. The tariff therefore raised the price of consumer goods in the South without providing a comparable boost to its economy. The impact of this imbalance was further exacerbated by a concurrent fall in the price of cotton, which crippled many farmers. ${ }^{26}$

By 1816, the tariff averaged 25 percent, and in 1824 it had risen to approximately $331 / 2$ percent. ${ }^{27}$ Then, in 1828, Congress passed the so-called "Tariff of Abominations," which raised duties on imports to $50 \% .{ }^{28}$ Opponents objected to the tariff on two grounds. First, they argued that a protective tariff was unconstitutional, since the Constitution only explicitly authorized revenue tariffs. ${ }^{29}$ Second, opponents decried the measure as an unjust redistribution scheme designed to "impoverish the planter, and to stretch the purse of the manufacturer." 30 Some even suggested secession from the perceived "most unequal alliance." 31 A great deal of the animosity and distrust between North and South during this period can thus be traced to the tariff controversy. As legal author William Watkins explained, "believing that they had made concessions to the Northern interest in order to serve the greater good in the postwar years, Southerners of the 1820 s searched their memories for instances of Northern reciprocity. Recalling none, many Southerners again embraced the doctrines of strict constructionism and localism." 32

The election of Andrew Jackson in 1828 temporarily cooled the controversy, as Southerners expected the Tennessean to reduce the tariff. ${ }^{33}$ Their optimism was

\footnotetext{
25 William J. Watkins, JR., Reclaiming the American Revolution: The Virginia and Kentucky Resolutions and Their Legacy (henceforth ReClaiming) 97 (2004).

$26 \quad$ Id. at 98.

27 Id.

28 Id. at 99.

29 Art. 8, Sec. 8, cl. 1 reads: "The Congress shall have Power To lay and collect Taxes, Duties, Imposts and Excises, to pay the Debts and provide for the common Defence and general Welfare of the United States." As in the 1798 controversy, however, proponents argued that the general welfare clause included unenumerated powers-here, the power to impose a protective tariff.

30 Thomas Cooper, Value of the Union Speech, in Reclaiming at 99.

31 Watkins, ReCLAIMING, supra note 25, at 99.

32 Id. at 101

$33 \quad I d$. at 99.
} 
misplaced, however; Jackson showed little interest in pressing for a reduction. ${ }^{34}$ That same year, the South Carolina legislature adopted the Exposition and Protest secretly drafted by Calhoun, which detailed South Carolina's discontent. ${ }^{35}$

In the Exposition and Protest, the sectional and counter-majoritarian nature of South Carolina's frustration becomes clear. "[T] he Tariff," Calhoun fumed, "gives them a prohibition against foreign competition in our own market, in the sale of their goods, and deprives us of the benefit of a competition of purchasers for our raw materials." ${ }^{\prime 36}$ South Carolina also accused the North of hypocrisy:

They assert that low prices are necessary consequences of excess of supply, and that the only proper correction is in diminishing the quantity... They also complained much of low prices, but instead of diminishing the supply as a remedy, they demanded an enlargement of their market by the exclusion of all competition in the home market. ${ }^{37}$

As a result of the conflict's sectional nature, South Carolina scoffed at the idea of proposing a constitutional amendment to remedy the situation. "How absurd then," Calhoun argued, "to compel one of the injured states, to attempt a remedy by proposing an amendment to be ratified by three fourths of the states, when there is by supposition a majority opposed to it." ${ }^{\prime 3}$ Indeed, if the tariff persisted, it was because a majority in Congress - where Northern representatives outnumbered Southern representatives - supported it.

Ultimately, it is this sectionalism and counter-majoritarianism which pushed South Carolina to adopt nullification, allowing resistance by an individual state. ${ }^{39}$ South Carolina's claim that the majority engaged in "despotism" was a direct challenge to James Madison's assurance in Federalist 50 that, under the Constitution, "the society itself will be broken into so many parts, interests, and classes of citizens, that the rights of individuals, or of the minority, will be in little danger from interested combinations of the majority." 40 Angered by the North's perceived "interested combinations," South Carolinians began to derive greater and

$34 \quad$ Id.

35 In doing so, Calhoun directly relied on Thomas Jefferson's Kentucky Resolutions — a copy of which he had requested to assist in his writing. Id. at 102.

36 Exposition and Protest Reported by the Special Committee of the House of Representative on the TARIFF; Read and Ordered to Be Printed, Dec. 19Th 1828 (henceforth Exposition AND Protest) 12 (Columbia, D.W. Sims 1829) (emphasis added). Id. at $17-18$.

Id. at 36 .

39 Calhoun's solution to the constitutional instability inevitably provoked by nullification further highlights nullification's counter-majoritarian nature. Calhoun argued that "the States themselves may be appealed to, three-fourths of which, in fact, form a power, whose decrees are the Constitution itself, and whose voice can silence all discontent." JAMES J. Kilpatrick, The Sovereign States: Notes of a Citizen of Virginia, 196 (1957). Under Calhoun's logic, a single state's interpretation of the Constitution remained legitimate until $3 / 4$ of the states overturned its interpretation by constitutional amendment; the disapproval of a simple majority would not suffice. The presumption of constitutionality favored the individual state rather than the collective. Nevertheless, Calhoun's solution recognized that state sovereignty under the Constitution was not unlimited. 
greater comfort from the idea that "the actual sovereign power, resides in the several states, who created it, in their separate and distinct political character," ${ }^{\prime 4}$ rather than in the assurance that ambition would counteract ambition through a federal system of checks and balances. ${ }^{42}$ Believing that the Constitution was "a compact, to which each state is a party," it was a small stretch for South Carolinians to conclude that each state was entitled to interpret and uphold that compact for itself. ${ }^{43}$

Following the publication of the Exposition and Protest in 1828, the South Carolina legislature debated how to proceed. The "nullifiers" in the legislature advocated calling a state convention to arrest the tariff's operation in South Carolina. The nullifiers' insistence on calling a convention - rather than simply nullifying the tariff through the legislature - reflected their and Calhoun's belief that "[s]tates are [the] instruments by which the people may assert their rights. ${ }^{\prime 44}$ A convention-in other words, a gathering of the people-embodied the idea that the states derived their authority from the people, but that the people expressed themselves politically through the states. Despite widespread discontent over the tariff, the legislature fell short of the two-thirds majority necessary to call a convention both in 1830 and 1831.

In 1831, during a statewide nullification campaign, then-Vice President Calhoun delivered his famous Fort Hill Address. In that address, he claimed Jefferson and Madison's 1798 writings on interposition and nullification as authority. He referred to both Madison's Report of $1800^{45}$ and the "illustrious Mr. Jefferson" as authority for the idea that "[t]his right of interposition, thus solemnly asserted by the State of Virginia, be it called what it may,-State-right, veto, nullification, or by any other name,- - I conceive to be the fundamental principle of our system. ${ }^{" 46}$ Nullifiers also claimed as authority Madison's statement in the Virginia Resolutions that "the states...have the right and are in duty bound to interpose... for maintaining, within their respective limits, the authorities, rights, and liberties appertaining to them"interpreting "respective" as an endorsement of individual state action. ${ }^{47}$

\footnotetext{
EXPOSITION AND PROTEST at 36.

Madison, supra note 40.

John C. Calhoun, Fort Hill Address, in Nullification: How to Resist Federal Tyranny in the 21st Century (henceforth Nullification) 197, 199 (Thomas E. Woods, Jr. ed., 2010).

44 Clyde N. Wilson, Nullification Reconsidered, in Nullification: Reclaiming the Consent OF THE GOVERNED 6, 8 (2016).

45 Madison wrote the Report of 1800 to respond to criticisms of his Virginia Resolutions of 1798.

46 Calhoun supra note 38 at 198-200. Though critics of Calhoun have claimed that his support for nullification was motivated by a desire to protect slavery rather than genuine opposition to the tariff, this view seems misplaced. See e.g. Keely N. Kight, Note: Back to the Future: The Revival of the Theory of Nullification, 65 MERCER. L. REv. 521, 532 (2014). While it is likely true that Calhoun assumed nullification could be used to assert South Carolina's perceived interests in the future - such as slavery - there is little evidence to suggest that Calhoun's opposition to the tariff was disingenuous or pretextual. As explained in the Exposition and Protest and other documents, South Carolinians were angered by the tariff's quantifiable and dramatic effect on Southern prices. Politicians today are often motivated by a variety of concerns, and it is unclear why we should assume Calhoun and his contemporaries were different.

47 Abel P. Upshur, No. I, in Nullification, supra note 43, at 230.
} 
That next year, in 1832, Congress passed a new tariff. Though it reduced the rate to 25 percent for certain goods, it retained the 50 percent rate for iron, wool and cotton; and, to add insult to injury for those who believed Congress could only collect duties to "pay Debts," the Treasury projected a surplus. ${ }^{48}$ South Carolinian nullifiers soon after succeeded in calling the state convention which would ultimately issue the Nullification Ordinance.

In a document entitled "An Ordinance To Nullify Certain Acts of the Congress of the United States, Purporting to be Laws, Laying Duties and Imposts on the Importation of Foreign Commodities," the convention declared the tariff "null, void and no law, nor binding upon this State, its officers or its citizens." ${ }^{49}$ This Ordinance did more than frustrate federal efforts to enforce the law in South Carolina; rather, it purported to invalidate the law completely. To enforce the Ordinance, the convention instructed the state legislature "to adopt such measures and pass such acts as may be necessary to give full effect to this Ordinance, and to prevent the enforcement and arrest the operation of the said acts and parts of acts of Congress of the United States within the limits of this State." ${ }^{50}$ The Ordinance further disallowed appeals "draw[ing] in question the authority of this Ordinance" to the Supreme Court. State officials were to take an oath to uphold the ordinance or their offices were to be "vacated" and "filled up as if such person or persons were dead or resigned." "Finally, the convention declared, any coercive action by the federal government against South Carolina would be interpreted as "inconsistent with the longer continuance of South Carolina in the Union." ${ }^{52}$ For South Carolina then, as it had been for Jefferson - who argued nullification would avoid "revolution and blood"53 — nullification was an alternative to upheaval and secession.

\section{B. CALHOUN AND the SANCTUARY Movement}

Comparisons between the sanctuary movement and the South Carolina nullifiers are thus inappropriate from both a theoretical and a practical perspective. Theoretically, South Carolina's actions were rooted in a version of compact theory which envisioned each individual state as a party to the Constitution. As such a party, South Carolina insisted on exercising its right to judge infractions of the constitutional compact. Practically, South Carolina's nullification operated through a convention, reflecting its conviction that the people act through the states, rather than directly through the federal government. ${ }^{54}$ Only after the convention issued its "Nullification Ordinance" could the state's General Assembly then implement nullification legislatively.

\footnotetext{
48 Watkins, ReCLAIming, supra note 25, at 107.

49 An Ordinance To Nullify Certain Acts of the Congress of the United States, Purporting to be Laws, Laying Duties and Imposts on the Importation of Foreign Commodities, in STATE Documents on Federal Relations: The States and the United States (henceforth Documents), 170, 171 (Herman V. Ames ed., The Lawbook Exchange 2nd ed. 2007) (1906).

Id.

Id. at $171-72$.

Id. at $172-73$.

3 Woods, supra note 43, at 164.

54 Indeed, before the passage of the $17^{\text {th }}$ Amendment, which allowed for the direct election of Senators, the Constitution more strongly reflected this view as well.
} 
As of Spring 2019, neither California nor any other state appears to have any plans to call a nullification convention to address the sanctuary issue. Neither has any state or city formally appealed to compact theory to justify its opposition to federal immigration policy - much less a version of compact theory which denies the collective nature of the constitutional order. Without compact theory and without a state convention, any comparison to South Carolina's nullification is destined to be superficial at best. Compact theory and convention-calling were not mere "addons" or formalities - they represented the basis of South Carolina's entire theory of the Union, and of nullification.

Legal author William Watkins of the Independent Institute summarized the issue succinctly: "Sanctuary cities do not base their actions on the constituent power of the people of the states. No special conventions have been held...Put simply, there is no nullification." 55

\section{JeFFERSON, Madison AND the SAnCtuary Movement}

Though the comparison between the South Carolina nullifiers and the sanctuary movement may be inapt, nullification - and the concerns underlying nullificationpredated the 1833 Crisis. Nullification originated with Thomas Jefferson in the 1790s, along with the related doctrine of interposition developed by James Madison. Therefore, theoretically, the sanctuary movement could be an instance of modern nullification without being akin to South Carolina's particular adaptation of that doctrine. Yet, in reality - as analysis of the origins of nullification revealsthe sanctuary movement remains fundamentally incompatible with the pre-Crisis understanding of nullification as well. More promising, however, than comparison to either iteration of nullification is that between the sanctuary movement and another oft-forgotten doctrine: interposition.

Complicating this differentiation, however, is nullification and interposition's closely-related history; the origins and development of these doctrines has been intertwined from the beginning. Both nullification and interposition are rooted in the claim that states have rights "under or beyond the Constitution to oppose federal authority;" 56 and both are grounded in the text of the 1798 Virginia and Kentucky Resolutions opposing the Alien and Sedition Acts.

Despite these similarities, an analysis of the Resolutions' authors' original intent and of the Resolutions' contemporaries' original understanding exposes substantial differences between these two doctrines. By identifying both similarities and differences, we may better understand the doctrines themselves, and better assess their potential relevance in our contemporary legal and political culture.

\section{A. NULLIFICATION AND INTERPOSITION: COMMON ORIGINS}

Historian Thomas E. Woods Jr. describes the perennial controversy surrounding nullification and interposition as revolving around the following question: "What

\footnotetext{
55 Watkins, supra note 24.

56 Neil H. Cogan, Introduction, in Union \& States' Rights supra note 1, at 3.
} 
was the United States supposed to be, anyway?" 57 He then continues, adding, "That may sound like an odd question. It is, in fact, the most important question of all." 58

That important question is by no means a new one. From the moment the Revolution ended, people argued about what the United States was or should be. Nationalists and centralizers clashed with decentralizers and localists. The states' first governing documents - the Articles of Confederation-embodied decentralizing, localist ideals. Many-Madison included-quickly became frustrated by the Articles, however. When a convention gathered in Philadelphia during the summer of 1787 to discuss revising the Articles, delegates argued about the optimal distribution of power among the states, and between the states and the as-of-yet created federal —or "general" 59 - government.

The debate did not end with what ultimately became the Constitutional Convention, or with the drafting of the Constitution, however. Many were suspicious of the new document, which they believed vested "absolute and uncountrolable power" in the central government. ${ }^{60}$ As economist Murray Rothbard noted, AntiFederalists perceived their "resistance to the Constitution" as being rooted in "the very ideology of Liberty versus Power that had sparked and guided the American Revolution." 61

Yet, just as the debate had not ended with the Constitution's drafting, it did not end with its ratification. Nineteenth-century journalist and Congressionalist minister Edmund Payson Powell described the perennial struggle as an inevitability, declaring: "It was destined that American history, down to the present time at least, should be a conflict of Hamiltonian and Jeffersonian ideas and methods" $"{ }_{2}$ - in other words, a conflict between centralizing and decentralizing visions. Whether or not the conflict was destined, it reignited with vigor in 1798 , barely a decade after the Constitution had come into effect. ${ }^{63}$

The events of 1798 have their origins in the geopolitical conflict between Britain and France. Despite having declared - and secured - their independence from Britain, the American states remained subject to European influence at the close of the 18th century. A debate soon emerged in the young republic as to whether the United States should align itself with Britain or with France, particularly as France and Britain went to war in $1793 .{ }^{64}$

\footnotetext{
Woods, supra note 43 , at 87.

Id.

The founding generation often called what we now refer to as the "federal government" the "general government."

60 Brutus, Excerpts from Brutus No. 1 (Bill of Rights Institute ed.), https://docs-of-freedom. s3.amazonaws.com/uploads/document/attachment/440/Brutus_No_1_Excerpts_ Annotated_Proof_3____pdf.

61 Murray Rothbard, Economic Determinism, Ideology, and the American Revolution, THE Rothbard Reader, 215, 225 (Joseph T. Salerno \& Matthew McCaffrey, ed. 2016).

62 Edmund Payson Powell, Nullification and Secession in the United States: A History of the Six Attempts During the First Century of the Republic, 52 (New York, G.P. Putnam's Sons 1898).

63 The Constitution became operative on March 4, 1789.

64 Watkins, Reclaiming supra note 25, at 11-12.
} 
In response to rising tensions with its former colonial master, the United States signed the Jay Treaty with Britain in 1795. Many Americans, still suspicious of the British and their sympathizers, felt the treaty failed to further American interests. ${ }^{65}$ Furthermore, they associated sympathy with Britain with sympathy for British institutions, and so interpreted the treaty "as a desire to establish an aristocracy after the British pattern." ${ }^{\prime 66}$ Meanwhile, they associated sympathy with the French, now in the midst of their own struggle for independence, with freedom and equality. ${ }^{67}$ Such disagreements about the propriety of the Jay Treaty precipitated the formation of the first American political parties - the Federalists and the Republicans. ${ }^{68}$ The Federalists became known as the party of the British, and the Republicans as the party of the French. ${ }^{69}$ Thus, a geopolitical conflict also morphed into a conflict of ideologies.

As a result, the French Revolution-which in many Americans' minds, had fast turned from inspiring to horrifying-further exacerbated tensions between the pro-British and pro-French factions. Even erstwhile supporters of the French revolutionaries, such as Jefferson himself, disavowed the Revolution's transformation from struggle for independence to Reign of Terror; despite such disavowals, Federalists began branding Republicans as unpatriotic supporters of anarchy and bloodshed. ${ }^{70}$

John Adams assumed office in 1797 amid these rising tensions. Soon after the United States signed the Jay Treaty, France responded by harassing American ships. $^{71}$ By the summer of 1798, hostilities between the United States and France had degenerated into the "Quasi-War" " - an undeclared, primarily Naval conflict which lasted about two years.

In response and with Adams' support, the Federalist Congress began by tightening naturalization requirements in the Spring of '98. This first Federalist bill increased the pre-naturalization residency requirement from 5 to 14 years. ${ }^{72}$ The Federalists likely hoped that these more stringent requirements would weaken the Republicans, who had been faring well among immigrant voters. ${ }^{73}$ Naturalization reforms enacted, the Federalists turned their attention to "aliens"-i.e. foreignersmore generally. ${ }^{74}$ To counter the supposed foreign threat, the Federalists proposed the Alien Enemies Act and Alien Friends Act. ${ }^{75}$ According to the language of the

\footnotetext{
Powell, at 56-57.

Id. at 57 .

Watkins, ReCLAIMING at 11-12.

Id. at $1-2$.

Id.

70 Powell, at 15; See also Luigi Marci Bassani, Liberty, State \& Union: the Political THEORY OF THOMAS JEFFERSON, 169 (2010).

Watkins, ReCLAImING, supra note 25, at 20.

Id. at 29.

Watkins, Reclaiming, supra note 25, at 28-29. See also Bassani, supra note 70, at 165. ("The Federalists' aversion to aliens was, naturally, of a political nature, for the latter were drawn en masse towards Thomas Jefferson's Democratic-Republican party.") There is nothing new about using the franchise as a weapon of partisan warfare. For contemporary examples of this issue, see e.g. Trip Gabriel, Voting Issues and Gerrymanders Are Now Key Political Battlegrounds, N. Y. Times (Jan. 2, 2019).

$74 \quad$ Id. at 30.
}

75 Id. 
day, "alien enemies," were citizens of nations with which the United States was formally at war, while "alien friends" were those from countries with which the Unites States was at peace. ${ }^{76}$ Though ostensibly designed to target the French "the truth is that all immigrants were looked upon with the same attitude of mistrust." "77

Republicans were particularly bothered by the Alien Friends Act, which they believed overstepped the Constitution. The Alien Friends Acts, signed into law in the summer of 1798, enabled the President to remove foreigners "dangerous to the peace and safety of the United States." ${ }^{"} 78$ While both parties generally accepted that the President's war powers enabled him to remove Alien Enemies, Republicans denied any such authority over citizens of countries with which the United States was not at war. ${ }^{79}$ Alien friends, they argued, "were exclusively subject to the sovereignty of the several individual states." ${ }^{80}$ Federalists, meanwhile, argued that the President's war powers extended to undeclared wars, or that, at the very least, the "necessary and proper clause" filled in any gaps. ${ }^{81}$

The Federalists not only passed laws touching aliens, however, but also American citizens. The Sedition Act, signed a few weeks after the Alien Acts, targeted dissenters writ large. ${ }^{82}$ The Act, which criminalized writing, printing, uttering or publishing "false, scandalous and malicious writing or writings against the government of the United States...with intent to defame said government," as well as material designed to bring the President or Congress "into contempt or disrepute," represented a striking curtailment of free speech. ${ }^{83}$ Republicans objected, insisting that the First Amendment's protections did not end where poor taste began.$^{84}$ Nevertheless, Federalists argued that such measures were necessary to maintain order in chaotic times. Federalists also had an ingenious response to Republican's constitutional challenge: the Sedition Act did not contravene the First Amendment because the First Amendment only protected speech to the extent traditionally protected under the British common law. ${ }^{85}$ The common law, meanwhile, criminalized "seditious libel" in terms similar to those of the Sedition

\footnotetext{
76 Watkins, ReClaiming, supra note 25, at 30.

Bassani, supra note 70, at 165.

An Act Concerning Aliens, in The Virginia Report of 1799-1800, Touching the Alien and Sedition Laws; Together with the Virginia Resolutions of December 21, 1798, The Debate and Proceedings Thereon in the House of Delegates of Virginia, and SeVeral Other Documents Illustrative of the Report and Resolutions (henceforth RANDOLPh's RePORT) 2, 2 (J. W. Randolph ed., Philadelphia, C. Sherman 1850).

79 Watkins, RECLAIMING, supra note 25 , at 30-31.

80 William Ruffin, In the House of Delegates: Friday, December 14, 1798, in RANDOLPH's REPORT 29 at 39. See also John Mercer, In the House of Delegates: Saturday, December 15, 1798, in Randolph's Report 40 at 44. Article I, Section 8 of the Constitution grants Congress the power "[t] establish a uniform rule of naturalization." Nowhere, however, does the Constitution explicitly grant Congress or the President power over the removal of foreigners - or any other aspect of immigration law.

81 Bassani, supra note 70, at 167.

82 See generally Sedition Act, in RANDOLPH's REPORT 19 AT 19-21.

83 Id. at 20. Conveniently, Republican Vice President Thomas Jefferson was not covered by the Sedition Act. Woods, supra note 43, at 43.

84 And some Republicans objections were truly in poor taste. Benjamin Franklin Bache, for example, derided Adams as being "blind, bald, crippled, toothless" and "querulous." Kilpatrick, at 67.

85 Bassani, supra note 70, at 166.
} 
Act. ${ }^{86}$ Federalists' argument rested on the assumption that the Constitution had in fact incorporated common law-by no means a foregone conclusion in that day. ${ }^{87}$

Compared to the Alien Acts, which were rarely if ever used, the Sedition Act claimed several high profile victims. All told, "at least 25 people were arrested for criticizing the government and approximately 14 were indicted." ${ }^{88}$ While these numbers may seem low, their impact was widely felt. "[B]y targeting writers and editors...the Federalists made the most of" the Sedition Act; "[i]nformation was scarce in the early Republic, and the Federalists attempted to hamstring the opposition press." 89

One early victim was Matthew Lyon, a bombastic and unyielding Congressman from Vermont. ${ }^{90}$ Lyon was indicted on three counts for 1) writing that Adams had scarified the public welfare "in a continual grasp for power" and in "thirst[ing] for a ridiculous pomp, foolish adulation, and selfish avarice;" 2) publishing a letter where the author suggested Adams should be sent to "a mad house;" and 3 ) assisting in the publication of seditious material..$^{91}$ Lyon was sentenced to four months in prison and a $\$ 1000$ fine, and Vermonters defiantly re-elected him as he served his sentence. ${ }^{92}$ Shortly thereafter, Supreme Court Justice Salmon P. Chase sentenced prominent lawyer Thomas Cooper to six months in prison and a $\$ 400$ fine for publishing a handbill critical of the Adams administration..$^{93}$ Chase also personally sentenced Scottish-born pamphleteer Thomas Callender to nine months in prison and a $\$ 200$ fine for criticizing the administration. ${ }^{94}$

Though the Federalists and their judges scored temporary victories against Lyon and the like, their heavy-handed approach only fanned the flames of opposition, and convictions created a pantheon of Republican martyrs. If Adams hoped the Alien and Sedition Acts would encourage domestic tranquility, he was sorely mistaken. Most significantly, his actions directly inspired the Virginia and Kentucky Resolutionsand the resulting doctrines of interposition and nullification.

86 Id.

87 Seee.g. J.W. Randolph, Preface, in RANDOLPH's REPORT i at xiv (writing that the incorporation of the common law "was regarded as an accumulation, at one stroke, of all authority in the hands of the Federal Government.") Contemporaries considered the issue of incorporation to be of critical importance. If British Common Law had simply been incorporated into the Constitution, Republicans argued, then America's prized written Constitution was little better than Britain's unwritten fundamental law. But see George K. Taylor, In the House of Delegates, Friday, December 21, 1798, in RANDOLPH's REPORT 122 at 135 for a Federalist defense of incorporation.

88 Watkins, supra note 25, at 43.

89 Id. at 54.

90 Lyon was once reprimanded by the House for spitting tobacco juice at fellow Representative Roger Griswold ( F - CT) in response to an insult, earning him the nickname "The Spitting Lyon." Griswold later retaliated by attacking Lyon with a cane - which attack Lyon deflected with a pair of fire tongs. Incivility, it would appear, is not a modern phenomenon. See e.g. Andrew Glass, Griswold-Lyon Fight Erupts on House Floor, Feb. 15, 1798, Politico (Feb. 15, 2011), https://www.politico.com/story/2011/02/griswold-lyon-fight-erupts-on-housefloor-feb-15-1798-049518.

91 Watkins, ReClaiming, supra note 25, at 45-46.

92 Id. at 47.

93 Id. at $48-51$.

$94 \quad I d$. at $51-53$. 


\section{B. NULLIFICATION: MEANINGS AND APPLICATION}

Nullification's primary aim is the defense of state sovereignty. It holds that a state may, by right, strike unconstitutional federal laws within its territory. Not only may individual states decide whether or not federal laws are constitutional, but they may also invalidate laws they deem unconstitutional. As a useful analogy, constitutional scholar Sanford Levinson has compared nullification to "the authority to issue an injunction" against federal law. ${ }^{95}$ A nullifying state acts as a kind of lower court, pending an appeal to the higher court of the states acting collectively to amend the Constitution. ${ }^{96}$

Underlying nullification are the concepts of consent, constitutionalism and compact theory. The doctrine itself was initially articulated by Thomas Jefferson in his draft of the Kentucky Resolutions of 1798, and then again by the Kentucky legislature in its Resolutions of 1799. Nullification was controversial from the beginning - even before the South Carolina Nullification Crisis. Then as now, both supporters and opponents understood nullification as embracing a strong role for the states, and a comparatively weaker role for the federal government.

\section{Nullification's Theoretical Origins}

The ideas underlying nullification predate the Quasi War, the tariff wars, or the Civil War. At its most basic, nullification rests on the idea of consent. ${ }^{97}$ By nullifying a law, a state expresses that it does not consent to the federal government's actions. As a philosophical matter, nullification rests on the Enlightenment idea that because people enjoy certain natural rights - i.e. rights which human enjoy by virtue of being human, rather than by virtue of any law or decree-government requires the consent of the governed. According to philosopher John Locke, people form governments to protect their natural rights to life, liberty and property; meanwhile, governments which fail to protect those rights lose the legitimacy provided by the people's consent. ${ }^{98}$

Relatedly, nullification also rests on the concept of constitutionalism-the idea that all government authority should be subordinate to a consented-to body of fundamental law. In such a constitutional system, laws must accord with the fundamental law - or constitution - to be considered legitimate. ${ }^{99}$ American constitutionalism inspired itself in part from the British constitutional tradition. ${ }^{100}$ Though the UK lacked (and still lacks) a codified and supreme constitution, movements such as the Levellers - who were active during the English Civil War-

95 Levinson, supra note 22, at 45.

96 Abel P. Upshur, No. I, in Nullification 217 at 220-21. Traditionally, the power to "nullify" had been associated with the judiciary.

97 See e.g. Brion McClanahan, Podcast Episode 92: Nullification and Consent (July 11, 2017), https://www.brionmcclanahan.com/blog/podcast-episode-92-nullification-and-consent/.

98 JoHn DunN, Locke: A VerY SHORT INTRODUCTION 34 (1984).

99 Alexander Hamilton for example, had argued such a position in Federalist 78. According to Hamilton, "[t]here is no position which depends on clearer principles, than that every act of a delegated authority, contrary to the tenor of the commission under which it is exercised, is void." The Federalist No. 78 (Alexander Hamilton).

100 See E. A. Dick Howard, The Bridge at Jamestown: The Virginia Charter of 1606 and Constitutionalism in the Modern World, 42 U. Rich. L. Rev. 9, 12 (2007). 
embraced the idea of constitutional supremacy, declaring in their "Agreement of the People" that "any laws made contrary to any part of the Agreement are null and void." "101 In ratifying the Constitution in 1787, the United States also embraced the idea of constitutional supremacy, preferring the security and consistency of a codified document to the British model of parliamentary supremacy. ${ }^{102}$

More recently, as Thomas E. Woods Jr. succinctly stated in the opening to his book, Nullification: Reclaiming the Consent of the Governed: "Nullification begins with the axiomatic point that a federal law that violates the Constitution is no law at all. It is void and of no effect." ${ }^{103}$ The idea that unconstitutional laws are void is - in a rare instance of agreement between a libertarian like Woods and a liberal legal scholar like Sanford Levinson-"uncontroversial."104 In 1798 as now, however, nullification is anything but uncontroversial. And, then as now, the controversy begins not with Woods's "axiomatic point," but with the "step further:" the idea that "if a law is unconstitutional and therefore void and of no effect, it is up to the states, the parties to the federal compact, to declare it so and thus refuse to enforce it." 105 As per Levinson, "presumably, the debate... is far more about who precisely gets to say whether - and when - a law is unconstitutional than about the abstract proposition that an unconstitutional law is really no law at all." ${ }^{106}$ Is it the people, the states, the courts, the President, Congress, or someone else? Indeed, a nullifying state operates not unlike a court-opining on a law's constitutionality and pronouncing a judgment binding within its jurisdiction. ${ }^{107}$

Finally, nullification is rooted in compact theory. ${ }^{108}$ Compact theory holds that "the United States had been formed when the people of each of the thirteen states, each acting in its sovereign capacity, ratified the Constitution," rather than from the action of "a single sovereign people." 109 And critically, under compact theory, the states ultimately retained their sovereign character after ratification-having only delegated, rather than relinquished, certain powers. As Woods explains, "[f]or compact theorists, therefore, nullification amounts to the legitimate exercise of sovereignty by sovereign bodies in defense of their liberties." ${ }^{110}$ If the states themselves are not the parties to the compact, then their authority to judge infractions

$101 \quad$ Id. at $16-17$.

102 Under the British model, the Constitution may be altered through acts of Parliament.

103 Woods, supra note 43, at 3.

104 Woods, supra note 43, at 3; Levinson, supra note 22, at 19 (stating that a law which violated the Second Amendment was "obviously" "null, void, and unenforceable).

105 Woods, supra note 43, at 3. In its entirety, Woods' statement reads: "Nullification begins with the axiomatic point that a federal law that violates the Constitution is no law at all. It is void and of no effect. Nullification simply pushes this uncontroversial point a step further: if a law is unconstitutional and therefore void and of no effect, it is up to the states, the parties to the federal compact, to declare it so and thus refuse to enforce it."

106 Levinson, supra note 22, at 19.

107 Tellingly, the term "nullify" was initially associated with court judgments. See e.g. Legislature of the State of New Hampshire, First Remonstrance of the Legislature, February 20, 1794, in Documents 12 at 12 (using the term "nullify" to describe an adverse judgment of a federal court against the state).

108 Legislature of the Commonwealth of Kentucky, The Kentucky Resolutions of 1798, in NullificATion, 157, 157.

109 Woods, supra note 43, at 88.

$110 \quad I d$. at 89. 
of that compact comes into question. In particular, however, nullification is rooted in a version of compact theory which conceives of the states individually, rather than collectively, as the parties to the compact. ${ }^{111}$ Therefore, under such a compact theory, the authority to judge infractions belongs to each state.

\section{Nullification's Textual Basis}

\section{a) Jefferson's Draft Resolves of 1798}

Though later removed by the Kentucky legislature, Jefferson famously used the term "nullification" in his draft of the Resolutions. Like the final Resolutions, Jefferson's draft resolves ${ }^{112}$ are organized into nine multi-paragraph sections called "resolves," each resolve addressing a distinct issue. Taken together, these resolves illustrate why Jefferson thought nullification useful, necessary, and justified.

Like the Resolutions, the draft resolves also open by declaring that the states "are not united on the principle of unlimited submission to their general government; but that, by compact... they constitute a general government for special purposes." ${ }^{.13}$ When that general government "assumes undelegated powers, its acts are unauthoritative, void, and of no force." 114 Furthermore, because there exists "no common judge" among the parties to the compact, "each party has an equal right to judge for itself, as well of infractions as of the mode and measure of redress." 115

The resolves then transition to criticizing particular government actions. The second resolve opposes the federalization of certain crimes. ${ }^{116}$ The third declares that the Sedition Act violates the First Amendment, while the fourth states that "alien friends are under the jurisdiction and protection of the laws of the state wherein they are." 117 The fifth states that the so called "Migration or Importation Clause" 118 further restricts federal power over immigration. ${ }^{19}$ The sixth asserts that the Alien Act violates due process. ${ }^{120}$ The seventh rejects the argument that the General Welfare or Necessary and Proper Clauses vest the government with any unenumerated powers. ${ }^{121}$

Jefferson's eighth resolve differs significantly from that adopted by the Kentucky legislature. In the Resolutions, the eighth resolve simply calls for the

111 Watkins, ReClaiming, supra note 25, at 72.

112 I will be referring to Jefferson's draft of the Kentucky Resolutions as his "draft resolves" or "resolves," to differentiate them from the document ultimately adopted by the Kentucky legislature.

113 Thomas Jefferson, Jefferson's Draft, in The Papers of Thomas JefFerson, https:// jeffersonpapers.princeton.edu/selected-documents/jefferson $\% \mathrm{E} 2 \% 80 \% 99 \mathrm{~s}$-draft.

114 Id.

$115 \quad I d$.

116 Id.

117 Id.

118 Id. Art. 1, Sec. 9, cl. 1 reads: "The Migration or Importation of such Persons as any of the States now existing shall think proper to admit, shall not be prohibited by the Congress prior to the Year one thousand eight hundred and eight, but a Tax or duty may be imposed on such

119 Id. Importation, not exceeding ten dollars for each Person."

120 Id.

121 Id. 
document to be transmitted to Kentucky's Senators and Representative, and encourages these "to use their best endeavors to procure... a repeal of the aforesaid unconstitutional and obnoxious acts." ${ }^{122}$ In the draft resolves, however, the eighth resolve is rather long and dense. Significantly, it is here that Jefferson explicitly espouses nullification, writing that "where powers are assumed which have not been delegated, a nullification of the act is the rightful remedy: that every State has a natural right in cases not within the compact...to nullify of their own authority all assumptions of power by others within their limits." ${ }^{23}$ In other words, Jefferson states that each individual state may nullify-i.e. judge the constitutionality of federal laws - within its own jurisdiction. The right to nullify is essential, Jefferson argues, because "without this right, they [i.e. the states] would be under the dominion, absolute and unlimited, of whosoever might exercise this right of judgment for them." ${ }^{24}$ Nullification is justified because the states "alone" are "parties to the compact, and solely authorized to judge in the last resort of the powers exercised under it, Congress being not a party, but merely the creature of the compact, and subject as to its assumptions of power to the final judgment of those by whom, and for whose use itself and its powers were all created and modified." ${ }^{25}$ After reiterating the substance of Kentucky's disagreement with Congress, Jefferson's draft closes with this call-also omitted from the Resolutions:

that the co-States, recurring to their natural right in cases not made federal, will concur in declaring these acts void, and of no force, and will each take measures of its own for providing that neither these acts, nor any others of the General Government not plainly and intentionally authorized by the Constitution, shall be exercised within their respective territories. ${ }^{126}$

Finally, the ninth resolve offers a sweeping indictment of both the spirit and substance of the Alien and Sedition Acts. ${ }^{127}$ Unless these and other violations be "arrested on the threshold," the resolve predicts that these "may tend to drive these states into revolution and blood." 128 Furthermore, failure to condemn the Acts "would be to surrender the form of government we have chosen, and live under one deriving its powers from its own will." ${ }^{129}$ Having cast the debate as one between peace and liberty, and violence and tyranny, the ninth and last resolve closes with a call for the co-states to recur "to their natural rights not made federal" and to concur in declaring the Acts "void and of no force."130 


\section{b) The Kentucky Resolutions of 1799}

Because Jefferson's draft resolves were neither adopted by the legislature, nor even available until after his death, the Kentucky Resolutions of 1799-which unlike the Resolutions of the previous year, actually refer to "nullification"-are a second important textual source for understanding nullification.

The Kentucky Resolutions of 1798 occasioned condemnation from state legislatures across the country; politicians in the sister states not only denounced the Resolutions, but state legislatures also issued "counter-resolutions" condemning the Kentucky document. ${ }^{131}$ In response to these criticisms, the Kentucky legislature reaffirmed the '98 Resolutions in November 1799, "[1]est...the silence of this commonwealth should be construed into an acquiescence in the doctrines and principles advanced...by the said answers." 132 These '99 Resolutions reiterated Kentucky's continued attachment to the Union, adherence to compact theory and conviction that Alien and Sedition Acts were unconstitutional.

Most significantly, however, the '99 Resolutions explicitly use the Jeffersonian term "nullification," which they describe as "the rightful remedy" to constitutional infraction. ${ }^{133}$ The Resolutions then assert that this remedy may be appealed to by an individual state. "[H]owever cheerfully it may be disposed to surrender its opinion to a majority of its sister states, in matters of ordinary or doubtful policy," Kentucky explains, "yet, in momentous regulations like the present...it would consider a silent acquiescence highly criminal." 134

Why the '99 Resolutions included the term "nullification" while the '98 Resolutions omitted it is unclear. ${ }^{135}$ Also unclear is the '99 Resolutions' authorship. They may have been drafted by Kentucky legislator John Breckenridge - who introduced them to the legislature — or by a committee of Kentucky notables. ${ }^{136}$

Indirectly, the '99 Resolutions may also have been influenced by Jefferson, whose comments regarding responses to sister-state criticism reached Breckenridge through Virginia legislator Wilson Cary Nicholas. ${ }^{137}$ Jefferson had written to Nicholas in September 1799 to inform him that he had encouraged Madison to issue a defense of the Virginia Resolutions of $1798 .{ }^{138}$ Such a response, Jefferson had suggested, should 1) answer sister-state objections, 2) reserve the right to respond to serious constitutional violations in the future, and 3) reiterate the state's attachment to the Union, and the constitution. ${ }^{139}$ Though the Kentucky legislature declined "to again enter the field of argument" in 1799 by systematically refuting sister-state objections, it did adopt Jefferson's general encouragement to reaffirm its commitment to the '98 Resolutions. ${ }^{140}$

\footnotetext{
131 See e.g. Replies of the States, in DocumenTs 16 at 16-26.

132 Woods, supra note 43, at 169.

133 Id.

134 Id. at 170.

135 Bassani, supra note 70, at 169.

136 Id. at 168.

137 Id.

138 Thomas Jefferson, Thomas Jefferson to Wilson Cary Nicholas, September 5, 1799, in THE Works of Thomas JefFerson In Twelve Volumes (Paul Leicester Ford, ed. 1904), http:// memory.loc.gov/service/mss/mtj/mtj1/021/021_1004_1005.pdf.

139 Id.

140 The Legislature of the Commonwealth of Kentucky, The Kentucky Resolutions of 1799, in NULLIFICATION 167 at 168.
} 


\section{Jefferson's Intent}

Jefferson intended the Resolutions as strong defenses of states' rights and constitutionalism, as well as of the individual liberties violated by the Alien and Sedition Acts.

First and foremost, however, in promoting nullification, Jefferson aimed to preserve what he considered to be the proper character of the United States: that of a federal union. As political theorist Luigi Marco Bassani has explained, "the resolutions can be deemed to be the core of Jefferson's federal idea, and they embody, in a nutshell, the whole of his constitutional doctrine." ${ }^{141}$ They are "first and foremost, an acknowledgement of the irreplaceable role played by the states in safeguarding the constitutional balance against the risk of consolidation of federal power." 142 Specifically, they are an acknowledgment of the role to be played by individual states - rather than simply the states collectively, as would be the case in a constitutional convention. Furthermore, they also highlight the connection between natural rights and states' rights. Jefferson believed both that states themselves enjoyed a variant of the natural rights enjoyed by individuals such as the right to consent to the exercise of power; and that individuals enjoyed certain rights - secured by, rather than created by, the constitutional order - by their very nature. ${ }^{143}$

Throughout his career, Jefferson championed limited and decentralized government. He was a localist skeptical of consolidated power, who believed government should operate at the lowest level possible. ${ }^{144}$ As a result, Jefferson considered federalism - the separation of powers between the state and "general" governments - a fundamental feature of American republicanism. ${ }^{145}$ A compact theorist, Jefferson considered the federal government an agent of the states, "subordinate to their own will." 146 The states, as Jefferson would write in a letter to the French philosopher Antoine Destutt de Tracy—were "the true barriers of

141 Bassani, supra note 70, at 163.

142 Id. at 175.

143 As Bassani explains: "Despite the ratification of the federal Constitution, Jefferson believed that vis-à-vis each other, the States remained like individuals in the "state of nature" retaining "natural rights with respect to one another... Jefferson's appeal to nullification was a peculiar application of the theory of natural rights:...the right of nullification, was entirely within the realm of the federal compact, and was by no means an extra-constitutional remedy. In Jefferson's opinion, such a right derived entirely from the nature of the American union, as it had been historically constructed." Luigi Marco Bassani, The Real Jefferson, Mises DAILY (May 23, 2002), https://mises.org/library/real-jefferson.

144 In his retirement from the presidency, for example, Jefferson promoted the idea of the "ward republic," whereby the majority of government functions would be performed at the level of the ward, i.e. a subdivision of a county. Thomas Jefferson, Thomas Jefferson to Joseph C. Cabell, Feb. 2, 1816, in The Writings of Thomas JefFerson (Andrew A. Lipscomb and Albert Ellery Bergh, eds., 1905), http://press-pubs.uchicago.edu/founders/ documents/v1ch4s34.html. Jefferson was also open to the idea of partitioning the American continent into multiple, independent republics. Thomas Jefferson, Thomas Jefferson to Joseph Priestly, Jan. 29, 2014 in supra note 134, https://memory.loc.gov/service/mss/mtj// mtj1/029/029_0998_0999.pdf.

145 Bassani, supra note $\overline{7} 0$, at 163. ("Jefferson felt that federalism was so important that it could at times override individual rights.")

146 Id. at 194. 
liberty." ${ }^{147}$ In other words, the states were the institutions which protected the rights of the people.

For Jefferson, the vision of federal power embodied in the Alien and Sedition Acts presented not only an immediate threat to individual liberties, but also to the structure and purpose of the United States' system of government. Jefferson certainly considered the Alien and Sedition Acts objectionable in substance, and not simply in principle. For example, Jefferson highly valued freedom of the press, which the Sedition Act clearly limited. ${ }^{148}$ Yet, Jefferson's aim in drafting the Kentucky Resolutions extended beyond his immediate concerns with the Acts themselves. In an October 1798 letter to Stevens T. Mason discussing the Alien and Sedition Acts, Jefferson wrote:

For my own part, I consider those laws as merely an experiment on the American mind, to see how far it will bear an avowed violation of the constitution. If this goes down we shall immediately see attempted another act of Congress, declaring that the President shall continue in office during life, reserving to another occasion the transfer of the succession to his heirs, and the establishment of the Senate for life. ${ }^{149}$

Jefferson feared the Federalist legislation was just the first blow to the United States' republican structure, and that other blows would follow. Similarly, a little over a month later, in a letter to John Taylor, Jefferson wrote: "I know not which mortifies me most, that I should fear to write what I think, or my country bear such a state of things." 150 Jefferson was alarmed by the widespread acceptance of the Federalist measures, and thought it essential to inspire opposition to the Acts - as well as to other instances of federal overreach. Failure to oppose the Acts, Jefferson feared, would erode the foundations of the American experiment.

That Jefferson advocated nullification as a means of combating federal overreach in general-rather than simply in the specific case of the Alien and Sedition Acts, or even simply in cases immediately infringing upon individual rights - is further highlighted by his inclusion of such other instances of federal overreach in his resolves. In his second resolve, for example, Jefferson decried the practice of federalizing crimes beyond those enumerated in the Constitution; ${ }^{151}$ in

147 Thomas Jefferson, Thomas Jefferson to Destutt de Tracy, January 26, 1811, in THE PAPERS OF THOMAS JEFFERSON (J. Jefferson Looney ed., 1811), https://founders.archives.gov/ documents/Jefferson/03-03-02-0258.

148 In an 1799 letter, for example, Jefferson wrote that "to preserve the freedom of the human mind and freedom of the press, every spirit should be ready to devote itself to martyrdom; for as long as we may think as we will, and speak as we think the condition of man will proceed in improvements." Adrienne Koch \& Harry Ammon, The Virginia and Kentucky Resolutions: An Episode in Jefferson and Madison's Defense of Civil Liberties, 5 WILL. \& MARY QUART. 145, 152, fn. 15 (1948).

149 Stevens T. Mason was a descendent of George Mason and the first governor of Michigan.

150 Thomas Jefferson, Thomas Jefferson to John Taylor, November 26, 1798, in THE PAPERS OF THOMAS JEFFERSON (Barbara B. Oberg ed., 2003), https://founders.archives.gov/documents/ Jefferson/01-30-02-0398.

151 Jefferson identified in the Constitution " $\mathrm{a}$ [federal] power to punish treason, counterfeiting the securities and current coin of the United States, piracies, and felonies committed on the high seas, and offences against the law of nations, and no other crimes whatsoever." Jefferson, supra note 109. 
particular, he criticized and declared "void" Congress's recent law criminalizing frauds against the Bank of the United States. ${ }^{152}$ Jefferson's seventh resolve also addressed constitutional interpretation, and advocated a narrow reading of phrases such as the General Welfare Clause. ${ }^{153}$

Though scholars such as Adrienne Koch and Harry Ammon have attempted to downplay the significance of states' rights and constitutionalism to Jefferson in drafting the Kentucky Resolutions, ${ }^{154}$ Jefferson's own words - both in the Resolutions themselves and his other writings - as well as the thrust of his career as a politician and political theorist, suggest otherwise. Jefferson, who called on states to recur to their "natural rights not made federal" to resist federal overreach, considered the states the irreplaceable and inherently legitimate guardians of American liberty and the American constitutional order.

\section{The Kentucky Legislature's Influence and Intent}

As the original author of the Kentucky Resolutions, Jefferson is an indispensable player in the story of nullification. Nevertheless, this story is incomplete without the inclusion of three other characters: Wilson Cary Nicholas, John Breckenridge, and to a lesser extent, John Taylor of Caroline. ${ }^{155}$ Nicholas passed on Jefferson's draft resolutions to Breckenridge, ${ }^{156}$ Breckenridge edited and introduced Jefferson's resolves to the Kentucky legislature, ${ }^{157}$ and Taylor assisted Jefferson in developing the idea of nullification (in addition to introducing Madison's draft resolutions in Virginia). ${ }^{158}$ In particular, Breckenridge's changes to the Resolutions partly explain why confusion about nullification's meaning abounded in the $19^{\text {th }}$ century, and continues to abound today.

Breckenridge's importance notwithstanding, there may never been "Kentucky" Resolutions without Nicholas. Jefferson had initially hoped that Nicholas, a member of the Virginia Senate with ties to North Carolina, would help introduce a draft of his Resolutions there. Nicholas, however, passed on the Resolutions to Breckenridge instead, apparently without Jefferson's prior knowledge. ${ }^{159}$ In

$152 \quad I d$.

153 Id.

154 Koch \& Ammon, supra note 148, at 174 ("However interesting these famous Resolutions may be for the constitutional doctrine they contain, they were intended primarily as a defense, practical and spirited, of civil liberties.").

155 Taylor, Nicholas, Breckenridge, Madison and Jefferson all belonged to the same social circle. Madison and Jefferson were, of course, neighbors and friends. Both Taylor and Nicholas were members of the Virginia legislature. Though Breckenridge was from Kentucky, he had practiced law in Jefferson's hometown of Charlottesville and had married into the Cabells, a prominent Virginia family. ETHELbert Dudley Warfield, The Kentucky Resolutions OF 1798: An Historical Study, 54-55 (New York, G.P. Putnam's Sons 1887).

156 Thomas Jefferson, Thomas Jefferson to Wilson Cary Nicholas, October 5, 1798, in The Papers of Thomas Jefferson (Paul Leicester Ford ed., 1904), https://memory.loc.gov/service/ $\mathrm{mss} / \mathrm{mtj} / / \mathrm{mtj} 1 / 021 / 021 \_0752 \_0752$.pdf (See also Woods, supra note 43, at 46.

157 Bassani, supra note 70 , at $17 \overline{3}$.

158 John Taylor, John Taylor to Thomas Jefferson, June 25, 1798, in The Papers of Thomas Jefferson (Barbara B. Oberg ed., 2003), https://founders.archives.gov/documents/ Jefferson/01-30-02-0313.

159 Jefferson approved of Nicholas's decision to involve Breckenridge. In a letter dated October 
addition, Nicholas acted as an intermediary between Jefferson and Madison. ${ }^{160}$ Nicholas also seems to have passed information between Jefferson and members of the Virginia legislature. ${ }^{161}$

Taylor, meanwhile, may have influenced Jefferson before the Resolutions were even drafted. In a June 1798 letter to Jefferson, for example, Taylor suggested that the "right of the State governments to expound the constitution, might possibly be made the basis of a movement towards its amendment. If this is insufficient, the people in state conventions, are incontrovertibly the contracting parties, and possessing the impinging rights, may proceed by orderly steps to attain the object." 162

Most dramatic, however, was Breckenridge's role. Breckenridge edited the text of Jefferson's draft resolves, all the while preserving much of the underlying theory. Most significantly, Breckenridge shortened Jefferson's eighth resolve, which contained the strongest expressions of state sovereignty of any version of the Resolutions. The version he introduced to the Kentucky legislature in November removed reference to the "rightful remedy" of "nullification," as well as some language suggesting that the states individually constituted the parties to the federal compact. ${ }^{163}$ However, Breckenridge returned to nullification during the debates that fall, stating: "I hesitate not to declare it as my opinion that it is then the right and duty of the several states to nullify those acts, and to protect their citizens from their operation." 164 He also compared the federal government to an "agent," seemingly in agreement with the omitted section on the nature of the federal compact. ${ }^{165}$

5, 1798, Jefferson wrote: "I entirely approve of the confidence you have reposed in $\mathrm{mr}$ Brackenridge, as he possesses mine entirely. I had imagined it better those resolutions should have originated with $\mathrm{N}$. Carolina. but perhaps the late changes in their representation may indicate some doubt whether they would have passed. in that case it is better they should come from Kentuckey." Jefferson, supra note 157.

160 Jefferson, supra note 131. In the aforementioned October 5 letter, Jefferson wrote to Nicholas: "I understand you intend soon to go as far as mr Madison's. you know of course I have no secrets for him. I wish him therefore to be consulted as to these resolutions." Id.

161 In a letter to Nicholas dated November 29, 1798, Jefferson suggests that his draft (i.e. those under consideration in Kentucky) be altered to read: "to concur with this commonwealth in declaring, as it does hereby declare, that the said acts are, and were ab initio, null, void and of no force, or effect." This language - not included in Madison's draft resolutions (i.e. those under consideration in Virginia)-later appeared in an intermediate version under discussion by the Virginia legislature. Thomas Jefferson, Thomas Jefferson to Wilson Cary Nicholas, November 28, 1798, in The Papers of Thomas Jefferson (Barbara B. Oberg ed., 2003), https://founders.archives.gov/documents/Jefferson/01-30-02-0399.

162 Taylor, supra note 153.

163 The relevant portion of the eighth resolve reads: "[T]hat in cases of an abuse of the delegated powers, the members of the General Government, being chosen by the people, a change by the people would be the constitutional remedy; but, where powers are assumed which have not been delegated, a nullification of the act is the rightful remedy: that every State has a natural right in cases not within the compact...to nullify of their own authority all assumptions of power by others within their limits: that without this right, they would be under the dominion, absolute and unlimited..." (emphasis added). Warfield, at 81.

164 Id. at 94.

165 Id. at 92. 
Ethelbert Dudley Warfield - a Presbyterian minister, college president, and descendent of John Breckenridge — speculated somewhat vaguely that Breckenridge "used such freedom in changing [the draft resolutions] to suit his own views and the observed wants of Kentucky." 166 Indeed, that Breckenridge removed Jefferson's most radical language suggests either that he did not agree with the language himself, or that he thought it would impede the Resolutions' passage or acceptance. Breckenridge's own statements, as well as the use of the term "nullification" in the Kentucky Resolutions of 1799, suggest that his changes were more so motivated by the later than the former. ${ }^{167}$

Though Breckenridge's changes may have aided the Resolutions' passage, they created confusion. Before the discovery of the draft resolves following Jefferson's death, Breckenridge's removal of the term "nullification" cast doubt on whether Jefferson himself had actually developed or even supported the idea. His removal of other phrases heavily suggestive of a right to individual state action - such as the last portion of Jefferson's draft resolve ${ }^{168}$ — also created doubt as to the practical aspects of nullification, such as the legitimacy of South Carolina's application of the doctrine.

\section{Contemporary Reception of the Kentucky Resolutions}

Because the Kentucky Resolutions of 1799 were issued the same week as George Washington's death, they attracted scant attention. ${ }^{169}$ The '98 Resolutions, by contrast, elicited strong and swift responses.

Overall, contemporaries interpreted the Kentucky Resolutions of 1798 as challenges to federal authority generally, and judicial authority specifically; they also interpreted them as attacks on the Alien and Sedition Acts. The Pennsylvania House, for example, denounced the Kentucky legislature for challenging the people's representatives - the President and Congress - and "the supreme judiciary." 170 "The constitution," it concluded, "does not contemplate, as vested or residing in the Legislatures of the several states, any right or power of declaring that any act of the general government 'is not law, but is altogether void, and of no effect." '"171 It then defended the Alien and Sedition Acts as "just rules of civil conduct, and as component parts of a system of defense against the aggressions of a nation, aiming at the dominion of the world" 172 and as containing "nothing terrifying, except to the flagitious and designing." 173

166 Id. at 166. Whatever Breckenridge's reasons, Warfield's conclusion that "Mr. Madison has expressed the most guarded sentiments. Mr. Breckenridge...holds a somewhat imperfectly defined middle ground, and Mr. Jefferson represents the most advanced type of States' rights" seems apt. Id. at 183-84.

167 Once it became clear that no state other than Virginia would join Kentucky in protest, the Kentucky legislature perhaps felt freer to express its feelings in stronger terms.

168 See supra note 109.

169 Watkins, ReClaiming, supra note 25, at 78.

170 The House of Representatives of the Commonwealth of Pennsylvania, Resolutions of the House of Representatives of Pennsylvania to Kentucky, February 9, 1799, in Documents at 20,20 .

171 Id.

172 i.e. France.

173 Id. at 21. 
Because the Kentucky Resolutions were both substantially similar and contemporaneous to the Virginia Resolutions, the documents were often conflated. For example, both New York and New Hampshire responded jointly to Kentucky and Virginia. New York decried these states' assumption of judicial power, ${ }^{174}$ while New Hampshire echoed these concerns, and also defended the Acts' constitutionality and expediency. ${ }^{175}$ Despite these initial conflations, contemporaries would soon come to interpret nullification and interposition differently, as evidenced by their selective appeal to these doctrines.

\section{Jefferson, the Kentucky Resolutions and the Sanctuary Movement}

Like its South Carolinian corollary, Jefferson and Kentucky's conception of nullification relied on the idea that states individually are party to the federal compact, and that the federal government is the agent of the several states. This conception challenged judicial supremacy - a fact seized upon by the Kentucky Resolutions' critics.

The sanctuary movement, by contrast, has appealed neither to compact theory nor the agency view of government, either legally or rhetorically. The sanctuary movement has based its opposition to the federal government in "anticommandeering" - a constitutional doctrine derived from the Tenth Amendment and articulated by the Supreme Court in the 1990s. ${ }^{176}$ The anti-commandeering doctrine states that the federal government cannot require states or state officials "to participate...in the administration of a federally enacted regulatory scheme."177 Anti-commandeering does not enable states to invalidate federal law. Neither does anti-commandeering depend on the unconstitutionality of the underlying law; it is state involvement in law enforcement, rather than the underlying law, which anticommandeering addresses. ${ }^{178}$ For example, supporters of California's sanctuary state law explicitly justified the bill with reference to anti-commandeering; ${ }^{179}$ yet, Gov. Jerry Brown clarified that " $[\mathrm{t}]$ his bill does not prevent or prohibit Immigration and Customs Enforcement or the Department of Homeland Security from doing

174 The Senate of the State of New York, Senate of New York to Virginia and Kentucky, in DOCUMENTS at 22, 22.

175 The House of Representatives of the State of New Hampshire, New Hampshire to Virginia and Kentucky, June 15, 1799, in Documents 24 at 24.

176 See e.g. Complaint, at 38, Chicago v. Sessions, No. 1:17-cv-5720 (N. D. Ill. Aug. 7, 2017); Complaint, 43, Philadelphia v. Sessions, No. 2:17-cv-03894 (E. D. Pa. Aug. 30, 2017) (explicitly identifying anti-commandeering as a justification for non-cooperation with federal authorities); Complaint, at 16, San Francisco v. Trump, No. 4:17-cv-00458 (N. D. Cal. Jan. 31, 2017) (citing Printz, the Supreme Court case articulating the anticommandeering doctrine, as a justification for not cooperating with federal authorities).

177 New York v. United States, 505 U.S. 144, 142 (1992); Printz v. United States, 521 U.S. 898 (1997)

178 For example, in the landmark anti-commandeering case Printz v. United States, petitioners challenged the Brady Act's enforcement mechanism-i.e. requiring local law enforcement to perform those checks - rather than the underlying constitutionality of background checks for gun sales. 521 U.S. at 904.

179 Taryn Luna, California to Become a Sanctuary State in 2018, The Sacramento BeE (October 5, 2017), http://www.sacbee.com/news/politics-government/capitol-alert/ article177212866.html. 
their own work in any way." 180 Similarly, sanctuary city Philadelphia's policies explain that "Philadelphia works with our federal partners and does not stop ICE from arresting Philadelphians whom they believe are undocumented."181

Practically, the sanctuary movement's primary mode of operation-cityor county-wide ordinances - also underscores the distance between its and the nullifiers' conception of the Union. Whether through the state legislature or a statewide convention, nullification has always envisioned the state-rather than any of its municipalities or subdivisions - as the appropriate organ of protest; the necessity of state action flows logically from nullification's focus on state sovereignty. Even Jefferson, who suggested that laws could be nullified by state legislatures rather than through a convention, ${ }^{182}$ saw nullification as something outside the normal law-making process - where a bill originates in the legislature and is then signed by the governor. Sanctuary state California, by contrast, used the normal law-making process to declare its sanctuary status. ${ }^{183}$

Finally, as exemplified by its reliance on judicially-articulated anticommandeering doctrine, the sanctuary movement has appealed to, rather than rejected, judicial supremacy. Rather than attempting to circumvent the courts, sanctuary cities have attempted to enlist the judiciary as an ally-filing complains in federal courts repetitive with next sentence to combat the Trump administration. ${ }^{184}$ This strategy has been largely successful, as sanctuary cities across the country have obtained injunctions barring the Trump administration from withholding federal funds from cities who limit their cooperation with ICE. ${ }^{185}$

Neither has the sanctuary movement asserted a general ability to ignore court orders. Philadelphia, for example, affirms its commitment to following court orders in the same document promoting its "Welcoming City" policy, explaining that

180 Jazmine Uolla, California Becomes 'Sanctuary State' in Rebuke of Trump Immigration Policy, The Los Angeles Times (October 5, 2017), http://www.latimes.com/politics/la-polca-brown-california-sanctuary-state-bill-20171005-story.html.

181 Stephanie Waters, Office of Immigration Affairs, City of Philadelphia Action Guide: Immigration Policies (Jan. 8, 2018), https:/www.phila.gov/2018-01-08-immigrationpolicies/.

182 The Kentucky Resolutions nowhere mention calling a state convention.

183 Ulloa, supra note 180.

184 See supra note 173.

185 See e.g. City of Philadelphia v. Sessions, 280 F. Supp. 3d 579(E.D. Pa. 2017), appeal dismissed sub nom. City of Philadelphia v. Attorney Gen. United States, No. 18-1103, 2018 WL 3475491 (3d Cir. July 6, 2018); City of Chicago v. Sessions, 264 F. Supp. 3d 933 (N.D. Ill. 2017), reconsideration denied, No. 17 C 5720, 2017 WL 5499167 (N.D. Ill. Nov. 16, 2017), and aff'd, 888 F.3d 272 (7th Cir. 2018), reh'g en banc granted in part, opinion vacated in part, No. 17-2991, 2018 WL 4268817 (7th Cir. June 4, 2018), vacated, No. 17-2991, 2018 WL 4268814 (7th Cir. Aug. 10, 2018); States of New York v. Dep't of Justice, 343 F. Supp. 3d 213 (S.D.N.Y. 2018); City \& Cty. of San Francisco v. Sessions, 349 F. Supp. 3d 924, 951 (N.D. Cal. 2018), judgment entered sub nom. California ex rel. Becerra v. Sessions, No. 3:17-CV-04701-WHO, 2018 WL 6069940 (N.D. Cal. Nov. 20, 2018); General City of Philadelphia v. Attorney Gen. of United States of Am., No. 18-2648, 2019 WL 638931 (3d Cir. Feb. 15, 2019) Notably, however, some courts have seemed suspicious of the anticommandeering argument, preferring to issuing injunctions on other grounds. See City of Philadelphia, 280 F. Supp. At 652; City of Chicago, 264 F. Supp. 3d at 949. Others have embraced the anti-commandeering argument, however. See States of New York, 343 F. Supp. 3d at 237; City \& Cty. of San Francisco, 349 F. Supp. 3d at 953. 
"Philadelphia's policies follow judicial orders" and that city prisons comply with judicial warrants; ${ }^{186}$ Los Angeles similarly affirms it will honor detainer requests "issued by a judicial body" in its February 2019 sanctuary resolution. ${ }^{187}$ Sanctuary cities' willingness to appeal to the courts and comply with court orders highlights the fact that the sanctuary movement views the judiciary as legitimate, and unique in its ability to decide legal questions.

\section{INTERPOSITION: MEANINGS AND APPLICATION}

Interposition's primary aim is the preservation of checks and balance and the protection of individual liberties. ${ }^{188}$ It holds that a state may, by right, shield its citizens from unconstitutional federal laws. A state may opine on the constitutionality of federal laws, and then oppose unconstitutional laws by denouncing them, encouraging their repeal, frustrating their enforcement, or calling for an amendment to the Constitution. Interposition is not, however, invalidation or injunction. Rather than acting as an independent court, as in the case of a nullifying state, the interposing state adopts the role of an advocate, arguing its case before the states collectively, and protecting its citizens from abuse within the established judicial system.

Like nullification, interposition relies on constitutionalism and, to a lesser degree, compact theory. James Madison advocated interposition in his Virginia Resolutions of 1798, then further developed the concept in his Report of 1800 . As with nullification, interposition was initially controversial in that it presented a challenge to judicial supremacy. The idea rapidly gained acceptance after the Alien and Sedition Crisis passed, however, and was repeatedly deployed to maintain the constitutional balance of power and resist federal encroachment on individual liberties.

\section{Interposition's Theoretical Origins}

Interposition is rooted in the idea that government must act within certain agreedupon parameters - in other words, constitutionally. Interposition is also rooted in the idea that the states, rather than being mere administrative jurisdictions or geographical designations, enjoy an independent political personality. To the extent that compact theory holds that the states were parties to the constitution, interposition, like nullification, reflects compact theory; it rejects the nationalist view that the federal government was created solely by the people.

186 Waters supra note 180.

187 City of Los Angeles, Resolution, http://clkrep.lacity.org/onlinedocs/2017/17-1040_reso_0908-2017.pdf; City Council Passes Resolution Declaring LA a Sanctuary City, CBS L. A. (Feb. 8, 2019), https://losangeles.cbslocal.com/2019/02/08/city-council-resolution-lasanctuary-city/. The resolution was introduced in 2017 but only formally approved in 2019.

188 In defining the primary aims of nullification and interposition differently, I am not suggesting that interposition does not aim to uphold state sovereignty, or that nullification does not aim to preserve checks and balances or protect individual liberties. Rather, it is a question of which aims predominate. Usually, all of these aims are compatible. Sometimes, however, these aims may clash: states may infringe on personal liberties, or one branch of government may act contrary to the popular will. Which party prevails depends on which aims decisionmakers prioritize. 
As legal historian Christian Fritz has explained, the concept of "interposition" came from the scientific thought of the day: "as used in astronomical and scientific texts of the period, it described the movement of something between two other things in a relationship so as to interrupt and bring attention to the essence of that relationship."189 In the political context, interposition thus reflects the view that the states - one of the parties to the compact - play a central role in regulating the constitutionally prescribed relationship between the federal government and the people.

\section{Interposition's Textual Basis}

James Madison famously used the term "interpose" in his Virginia Resolutions of 1798. ${ }^{190}$ The Virginia Resolutions are shorter than their companion documents in Kentucky, but adopt a similar structure; they are organized into ten short paragraphs.

In the first and second paragraphs, the Resolutions express the state's attachment to the Constitution and to the Union. ${ }^{191}$ In the third paragraph, they introduce the idea of interposition. The Resolutions "explicitly and peremptorily declare" that the federal government's powers result from "the compact to which the states are parties," and that the states, as parties, "have the right, ${ }^{192}$ and are duty bound, to interpose, for arresting the progress of the evil, and for maintaining, within their respective limits, the authorities, rights, and liberties, appertaining to them." 193

Interposition has become necessary, the third paragraph explains, because of the government's tendency to "enlarge its powers by forced construction of the constitutional charters." Especially egregious has been the government's use of the constitution to justify the Alien and Sedition Acts. Both Acts, the Resolutions argue, exercise "power not delegated by the Constitution." 194 They particularly criticize the Sedition Acts, which attacked "the right of freely examining public characters and measures, and of free communication among the people thereon, which has ever been justly deemed the only effectual guardian or every other right." 195

In closing - and as a clue to what interposition could involve in practicethe Resolutions reassert Virginia's commitment to the Union before calling for the states to "concur with this commonwealth, as it does hereby declare, that the acts

189 Fritz, supra note 1, at 2-3.

190 James Madison, Resolutions of Virginia of December 21, 1798, in RANDOLPH's REPORT 22 at 22. Madison did not, however, invent the practice of using the state legislature to oppose unconstitutional actions. In 1790, the Virginia Assembly issued a "memorial" opposing the federal government's assumption of state debt. The Assembly described themselves as "guardians... of the rights and interests of their constituents, as sentinels placed by them over the ministers of the foederal [sic] government, to shield it from their encroachments, or at least to sound the alarm when it is threatened with invasion." According to the Assembly, the assumption of debts deserved "censure" because it was "not warranted by the constitution of the United States." The General Assembly of the Commonwealth of Virginia, Virginia On the Assumption of State Debt, December 16, 1790, in Documents 4 at 5-6.

191 Id.

192 Notably, however, the Virginia Resolutions do not refer to the right of interposition as being a "natural right" of the states.

193 Id.

194 Id. at 23.

195 Id. 
aforesaid are unconstitutional" and requesting that the governor "transmit a copy of the foregoing resolutions to the executive authority of each of the other states." 196

\section{Madison's Intent}

Madison intended the Virginia Resolutions as a defense of both individual liberties and checks and balances. Rather than seeking to encourage states to "annul" unconstitutional legislation within their borders, Madison meant the Resolutions as a "warning to call the federal government to a halt, made public in order to induce those who were originally party to the constitutional compact to join in... protest." 197 Though concerned by the constitutional implications of Federalist policies, Madison's primary aim was opposing the Alien and Sedition Acts.

In drafting the Resolutions, Madison adopted a cautious, consensus-building approach. While the Kentucky Resolutions opened by emphasizing the states' reserved power, the Virginia Resolutions opened on a cooperative and conciliatory note emphasizing their attachment to the Constitution and "to the union of the states." "198 And while Jefferson's draft resolves unequivocally pronounced the Acts "null and void" and embraced individual state resistance, Madison sidestepped such a robust embrace of state's rights. Madison also declined to elaborate on what "interpos[ing] for arresting the progress of...evil" would involve in practice. Indeed, in a December 20 letter to Jefferson, Madison wrote that he had purposefully used "general expressions that would leave to other States a choice of all the modes possible of concurring in the substance, and would shield the General Assembly [of Virginia] against the charge of usurpation." ${ }^{199}$ In other words, Madison did not want disagreements about the nature of the federal compact to stop states otherwise opposed to the Acts from concurring with Virginia. "[B]y leaving the widest possible range of action for the states to take" Madison "sought to reach sympathizers in every state, provide them with a platform from which to attack the measures of the government, and thus leave to them the problem of the form their responses should take. ${ }^{200}$ By remaining vague, Madison was able to craft resolutions acceptable to both himself, and, hopefully, to others.

***

Madison lived until 1836, giving him the opportunity to witness - and denounce - South Carolina's adaptation of his and Jefferson's ideas in the early 1830s. ${ }^{201}$ Though Madison's interpretation of interposition with 30+ years' hindsight could not on its own be decisive evidence of his intent in 1798, his 1830s' pronouncements were consistent with his overall political philosophy-lending credibility to his late-in-life claim that he had not intended interposition to involve invalidation of federal law by a single state. Rather, Madison claimed that he had intended his Resolutions as a call to collective action by the states, "conceiv[ing] of the issue as the right of the states to declare - that is, to make it publicly known

\footnotetext{
Id.

Bassani, supra note 70, at 94 (internal quotations removed).

Woods, supra note 43, at 147.

Id.

200 Editorial Note, Virginia Resolutions, in The Papers of JAmes Madison (David B. Mattern et al., ed., 1991), http://founders.archives.gov/documents/Madison/01-17-02-0128.

201 Jefferson had died a decade earlier, in 1826.
} 
...- - that any laws of the United States found to overstep their delegated powers should be regarded as unconstitutional." ${ }^{202}$

Though Madison personally opposed the "Tariff of Abominations," he disavowed Calhoun's "novel and nullifying doctrine," 203 which he feared not only misrepresented his work and Jefferson's work, but also the nature of the Union. ${ }^{204}$ Madison penned his "Notes on Nullification" in 1835 in an attempt to discredit the claim that his and Jefferson's writings vindicated the South Carolinians. In that work, an exasperated Madison complained that despite the Virginia legislature's disavowal, the "resolutions are still appealed to as expressly or constructively favoring the doctrine" of nullification. ${ }^{205}$ Madison criticized the nullifiers' view that "a single state has a constitutional right to annul or suspend the operation of a law of the U. S. within its limits" all the while "remaining a member of the Union, and admitting the Constitution to be in force;" rather than advocating such unilateral action, Madison insisted, both Resolutions aimed "to produce a conviction everywhere, that the Constitution had been violated by the obnoxious acts and to procure a concurrence and co-operation of the other States in effectuating a repeal of the acts." ${ }^{206}$ The proper remedies to federal usurpations, Madison argued, were first "the checks provided among the constituted authorities, second "the Ballotboxes," and third, constitutional amendment. ${ }^{207}$

Yet, beyond the vague calls for "concurrence and co-operation," Madison's Notes - like the Virginia Resolutions themselves - assiduously avoided defining "interposition" in unique and practical terms. Even in an 1833 letter to his friend William Cabell Rives, Madison remained vague, only explaining that

The object of Virga. was to vindicate legislative declarations of opinion, to designate the several constitutional modes of interposition by the States agst. abuses of power; and to establish the ultimate authority of the States as parties to \& members of the Constitution, to interpose agst. the decisions of the Judicial as well as other branches, of the Govt. ${ }^{208}$

202 Bassani, supra note 70, at 194.

203 Madison to W. Rives, March 12, 1833; see also Watkins, supra note 24,, at 112-13.

204 As Christian Fritz explains: the Resolutions of ' 98 and the Nullification Crisis "were not exclusively about federalism. They also raised key questions of constitutionalism: Who were 'the people' that underlay the national constitution and how could that sovereign act and be recognized in action." Fritz, supra note 1, at 166.

205 James Madison, Notes on Nullification (henceforth Notes), in 9 The Writings of JAmES Madison: Comprising his Public Papers and His Private Correspondence, Including Numerous Letters and Documents Now for the First Time Printed (Gaillard Hunt ed. 1900), $573,574$.

$206 \quad I d$

207 Id a a 597. Ironically, this argument approximates Federalist Henry Lee's argument in opposition to the Virginia Resolutions. See Henry Lee, In the House of Delegates, Thursday, December 20, 1798, in RANDOLPH's REPORT 103 at 104, 108.

208 James Madison, James Madison to A. Rives, January 1, 1833, Early Access Version, in The Papers of James Madison, https://founders.archives.gov/documents/ Madison/99-02-02-2655. 
Though Madison blamed the nullifiers" "nullifying misconstruction"209 on a deliberate misinterpretation of his statement that "the states... have the right and are in duty bound to interpose...for maintaining, within their respective limits, the authorities, rights, and liberties appertaining to them," Madison's intentionally capacious language is at least as much to blame. As Virginia judge Abel P. Upshur asked rhetorically in his "An Exposition of the Virginia Resolutions of 1798:" if a state could not act upon its determination that a law is unconstitutional, then "is its right of judgement any thing more than a mere liberty of speech and of opinion, and, therefore, no available right at all?" 210 Through an abundance of caution in 1798, Madison opened the door to misinterpretation in 1833. That South Carolina was not unique in construing Madison's words as an invitation to individual state action is also demonstrated by contemporaries' reactions. ${ }^{211}$

As a result, some scholars have criticized Madison for a perceived inconsistency, calling him "a superficial and inconsistent thinker" who contradicted "his own plain language" of 1798 by opposing state resistance in $1832 .{ }^{212}$ Yet, an examination of Madison's writings and career suggests that while he may have somewhat mischaracterized the principles of ' $98,{ }^{213}$ his response to South Carolina was consistent with his own political philosophy. Throughout his career, Madison emphasized the importance of checks and balances in the pursuit of securing personal liberties. For Madison, state action was one of many means by which that balance and those liberties could be maintained.

Unlike Jefferson, who believed "the true barriers of our liberty in this country are our state-governments, ${ }^{214}$ Madison was often skeptical of the states. Madison repeatedly observed that state governments, rather than acting as "true barriers of liberty," often violated the rights of their citizens. In his 1787 "Vices of the Political System of the United States," for example, Madison criticized the power-and misuse of power-by state governments under the Articles of Confederation. Of state laws, he wrote, "their number is the price of liberty." 215 Part of the solution hinted at in "Vices" was that ultimately adopted in the Constitution: balancing competing interests through the separation of powers. ${ }^{216}$ Only through such a balance could "private rights" be secure. ${ }^{217}$ Madison dismissed the decentralized Articles as "nothing more than a treaty of amity of commerce and of alliance," and advocated

209 Madison, Notes at 580.

210 Upshur, supra note 96 at 121.

211 See supra, notes 237-44.

212 Wilson, Jefferson and Nullification, in Nullification: ReClaiming the CONSENT of the GOVERNED 1 at 3.

213 In his Notes, for example, Madison insists that Virginia was "so far...from countenancing the nullifying doctrine, that the occasion was viewed as a proper one for exemplifying its devotion to public order, and acquiescence in laws which it deemed unconstitutional, whilst those laws were not constitutionally repealed." Describing Virginia's spirited protest as "devotion" and "acquiescence" seems to misrepresent the spirit of the moment. Madison, supra note 185 at 192.

214 Jefferson, supra note 142.

215 Madison, Vices of the Political System of the United States, in The PAPers of James Madison (William T. Hutchinson ed. 1962), 353, http://pjm.as.virginia.edu/sites/pjm. as.virginia.edu/files/vices-political-system-linked-pages.pdf.

$216 \quad I d$. at 357.

217 Id. 
for a more robust governing document. ${ }^{218}$ Frustrated with state intransigence, Madison proposed amending the Articles to allow the federal government to compel states "to fulfill their federal engagements." ${ }^{219}$ A few years later, Madison expressed similar skepticism of state governments at the Philadelphia Convention; there, he advocated a federal veto of state legislation. ${ }^{220}$ Though Madison's federal veto was ultimately rejected, Madison continued to criticize state governments even as he urged the adoption of the Constitution. ${ }^{221}$

Furthermore, even in his own Virginia Resolutions, Madison arguably avoided the positions which the nullifiers ascribed to him. First, Madison never clearly called for states to invalidate federal law, preferring the term interpose-which suggests an intermediary role as an agent of protest, rather that of a final arbiter. Even Koch and Ammon, who conflate Madison and Jefferson's thought throughout their article, admit that Madison "did not think, as did Jefferson, that under the Constitution the state was justified in declaring federal laws 'null, void, and no effect.' ${ }^{222}$ Nor did he believe that the state was the ultimate judge of both the violation and the mode of redress." ${ }^{223}$ Second, Madison never clearly endorsed the individual-state view of compact theory, stating only that "the states"-in the plural- "are parties." Madison reiterated this position in his Report of 1800, writing: "The states, then, being the parties to the constitutional compact, and in their sovereign capacity, it follows of necessity, that there can be no tribunal above their authority... and consequently, that, as the parties to it, they must themselves decide, in the last resort, such questions as may be of sufficient magnitude to require their interpretation." 224 For Madison then, "[i]t was the collective nature of this compact as binding all states, rather than as a compact between each individual state and the Union, that exposed a decisive flaw in the South Carolina position.",225

Madison's apparent reversal in 1798 was then not so much a change of mind as a change of strategy brought about by a change of circumstance. Unlike in 1787, it was the federal government, rather than the state governments, which appeared to pose the greatest danger to the people's liberties in 1798. As historian Kevin Gutzman has explained, Madison's thinking about federalism was "variable," and reflective of the relative strengths of the federal and state governments at different times."226 Though Madison "pursued a consistent vision of the ideal polity," "[c]onsistent theory yielded to political imperative."227 In 1798, "after a solid decade of political defeats, Madison was casting about for some means of protecting

218 Id. at 351.

219 Jack N. Rakove, “A Real Nondescript:” James Madison's Thoughts on States'Rights and Federalism, in Union \& StaTeS' Rights, supra note 1, at 16.

220 Hutchinson, supra note 215 , at 347.

221 For example, Madison wrote in Federalist 51: "It can be little doubted that if the State of Rhode Island was separated from the Confederacy and left to itself, the insecurity of rights under the popular form of government within such narrow limits would be displayed by such reiterated oppressions of factious majorities." FEDERALIST PAPERS No. 51 (James Madison).

222 Koch \& Ammon, supra note 148, at 162.

223 Id.

224 Madison, in Woods, supra note 43, at 176 (emphasis added).

225 Rakove, supra note 219, at 26.

226 Id. at 570.

227 Id. 
minority rights against what must have seemed a perpetual Federalist attack." ${ }^{228} \mathrm{~A}$ "practical politician," Madison thus turned to states' rights in 1798, as it seemed the argument best suited to his aim of countering the Federalist assault on civil liberties. ${ }^{22}$ Indeed, as Madison candidly admitted in a letter to Virginia Senator William Rives: "In explaining the proceedings of Virga. in 98-99, the state of things at that time was the more properly appealed to, as it has been too much overlooked. The doctrines combated are always a key to the arguments employed." 230

While Madison was willing to use states' rights arguments in 1798 to protect civil liberties and restore the constitutional balance of power, he was not willing to deploy those arguments in defense of South Carolina's sectional interests. Unlike the Alien and Sedition Acts, the tariff did not encroach upon personal liberties, or an area reserved for state regulation.

Perhaps most revealing, however, was Madison's objection to the nullifiers' view that "the States have never parted with an Atom of their sovereignty; and consequently that the Constitutional hand which holds them together, is a mere league or partnership, without any of the characteristics of sovereignty or nationality." 231 He worried that "the discourse of federalism was degenerating into a contraposition of two absolute and simplistic formulas" - one based on the absolute sovereignty of the states, and the other on the existence of a unitary American people. ${ }^{232}$ Rather than restoring the balance Madison so prized, South Carolina's actions seemed to Madison to threaten the stability of the Union by tilting the scales in favor of the states and turning back the clock to the Articles. The Father of the Constitution may have suddenly feared he would be remembered as the Father of Disunion. ${ }^{233}$

\section{The Virginia Legislature's Influence and Intent}

Overall, Virginia legislators appear to have been animated by a variety of concerns - asserting state sovereignty, upholding the Constitution, preserving the Union, and defending individual liberties. Like Madison, however, the Virginia legislature ultimately opted to issue resolutions which would inspire broad-based support, though some members also personally supported the more robust vision of resistance embodied in the Kentucky Resolutions.

The final edits to the Virginia Resolution distanced these from their companion documents in Kentucky by de-emphasizing the nullity of unconstitutional laws and the right to individual state action. First, the Virginia legislature voted to remove

228 Kevin R. Gutzman, A Troublesome Legacy: James Madison and "The Principles of '98", 15 (4) Journal of the Early Republic, 569, 579 (1995).

229 Id. at 571.

230 James Madison, James Madison to William C. Rives, March 12, 1833, in Hunt at 511, 514.

231 Id. Madison was likely not overstating the nullifiers' view. In his "Discourse on the Constitution and Government of the United States," Calhoun described the federal government's powers as "trust powers." He denied that the states had "absolutely transferred" their powers to the federal government, or that they had formed a "national" government. John C. Calhoun, $A$ Discourse on the Constitution and Government of the United States, in 1 THE WORKS OF John C. Calhoun 111, 113, 143 (Columbia, A. S. Johnston, Richard K. Cralle ed., 1851).

232 Rakove, supra note 219, at 14.

233 For a similar conclusion see Kevin R. Gutzman, From Interposition to Nullification: Peripheries and Center in the Thought of James Madison, 46 Essays IN History 89, 89 (1994). 
language declaring the Alien and Seditions Acts "null, void, and of no force, or effect." 234 Significantly, the "null and void" language had not been in Madison's initial draft, but had been added at Jefferson's suggestion before the resolves were introduced in the legislature. ${ }^{235}$ The legislature's "change of the change" therefore returned to Madison's original wording and intent.

While the removal of the "null and void" language is quite telling in regards to Madison's intent, it should not be interpreted as meaning that the legislature as a whole rejected the idea that unconstitutional laws were null and void. Virginia Del. Johnston, for example, stated that "whether the laws were said by the committee to be null and void, or not, was a matter, he thought, of little consequence. For if they were unconstitutional, they of course, were null and void." ${ }^{236}$ Similarly, Del. Daniel explained that

[i]t had been contended by gentlemen, that it was going too far to declare the acts in question, to be 'no law, null, void, and of no effect:' that it was sufficient to say they were unconstitutional. He said, if they were unconstitutional, if followed necessarily that they were 'not law, but null, void, and of no effect.' But, if those particular words were offensive to gentlemen he had no objections to any modification, so the principle was retained." ${ }^{237}$

Whether or not Dels. Johnston or Daniel considered the right of declaring laws "null and void" as belonging to individual states or the states collectively is unclear from these comments. Comments by other delegates, however, suggest sympathy towards the individual state action position. Del. Foushee, for example, supported the Resolutions by stating that "the states individually were sovereign before and at the time of the adoption of the Constitution... and still are." 238

Also difficult to interpret is a second change to the Resolutions - the removal of the word "alone" from the statement that the "states alone are parties" to the compact; ${ }^{239}$ the change was little discussed. Likely, however, the omission reflected the view of at least some in the legislature that both the states and the people were parties to the compact, while still rejecting the Federalist view that the people alone were parties. ${ }^{240}$ Like the edits to Jefferson's draft resolutions, the Virginia changes

234 In the House of Delegates, Friday, December 21, 1798, in RANDOLPH's RePORT 122 at 150.

235 Watkins, ReClaiming, supra note 25 , at 72.

236 Peter Johnston, In the House of Delegates, Thursday, December 20, 1798, in RANDOLPH's REPORT 103 at 111.

237 William Daniel, Jr., In the House of Delegates, Thursday, December 19, 1798, in RANDOLPH's REPORT 81 at 97.

238 William Foushee, In the House of Delegates, Thursday, December 18, 1798, in RANDOLPH's REPORT 71 at 76.

239 See William B. Giles, In the House of Delegates, Friday, December 21, 1798, in RandolPh's REPORT 122 at 149; Wilson C. Nicholas, In the House of Delegates, Friday, December 21, 1798, in RANDOLPH's RePORT 122 at 149; Commentary to John Taylor, In the House of Delegates, Friday, December 21, 1798, in RANDOLPH's REPORT 122 at 150.

240 Federalist Henry Lee was one of the most enthusiastic proponents of the "people alone" view. During the legislative debate, Lee "contended that the ruling principle in the resolutions was erroneous. They asserted as a fundamental position, that the existing Constitution was a compact of states. He denied that position: declaring the Constitution to be a compact 
also betrayed a certain ambivalence, even among Republicans, towards the vigorous Jeffersonian version of states' rights. Nevertheless, even the comparatively more modest state role envisioned by Madison and the Virginia legislatures far exceeded that acceptable to the Federalists.

Indeed, Virginia legislators consistently highlighted the Federalists' perceived disregard for the separation of powers, which they considered not only constitutionally indefensible, but also dangerous. Del. Ruffin explained that "Congress alone could determine war or peace: consequently alien enemies were proper subjects for congressional approval: but that alien friends were exclusively subject to the sovereignty of the states." ${ }^{241}$ Del. Allen insisted that the Migration and Importation Clauses disallowed congressional interference with immigration. ${ }^{242}$ And, even if Congress could pass a law to remove alien friends, he argued, it had no right to vest that power in the President. ${ }^{243}$ For these and other delegates, the balance of power would be preserved through a narrow, textualist reading of the Constitution. ${ }^{244}$ Del. Daniel, for example, railed against the "doctrine of implication" (i.e. of implied constitutional powers) as he urged his colleagues to ratify the Virginia Resolutions. ${ }^{245}$

Furthermore, for Republicans, threatening the balance of power threatened the unity and security of the country itself. John Taylor, for example, warned "that oppression was the way to civil war...The way to stop civil war, would be to stop oppression." 246 The legislature's explanatory "Address of the General Assembly to the People of the Commonwealth of Virginia," issued in January 1799, also emphasized that "acquiescence of the states, under infractions of the federal compact, would ... prepare the way for a revolution." ${ }^{247}$ While commentators today often link interposition and nullification with secession, the Resolutions' supporters considered these doctrines as alternatives to disunion. Del. Mercer similarly argued that the Resolutions, by preserving the Constitution, were also preserving the Union. ${ }^{248}$

Yet as the delegates attacked the Acts' constitutional implications, they also decried their immediate effects on individuals. Del. Barbour justified the Resolutions in part by touting the states' roles as protectors of personal freedoms,

among the people." See Henry Lee, In the House of Delegates, Thursday, December 20, 1798 , in RANDOLPH's REPORT, at 103, 104. Lee also proposed an amendment to the resolves reflecting his view. The amendment was rejected 104-60. See supra note 213 at 156.

241 William Ruffin, In the House of Delegates, Thursday, December 14, 1798, in RANDOLPH's REPORT 29 at 39.

242 John Allen, In the House of Delegates, Thursday, December 16, 1798, in RandolPH's REPORT 40 at 53.

243 Id.

244 See generally H. Jefferson Powell, The Principles of '98: An Essay in Historical Retrieval, 80 VA. L. Rev. 689 (1994) for argument that Virginia and Kentucky Resolutions 1798 promoted a textualist reading of the Constitution.

245 William Daniel Jr., In the House of Delegates, Thursday, December 19, 1798, in RANDOLPH's REPORT 81 at 98.

246 John Taylor, In the House of Delegates, Thursday, December 13, 1798, in RandolPH's REPORT 24 at 28.

247 Woods, supra note 43, at 152.

248 John Mercer, In the House of Delegates, Thursday, December 15, 1798, in RandolPh's REPORT 40 at 41. 
arguing that "state legislatures being the immediate representative of the people, and consequently the immediate guardians of their rights, should sound the tocsin of alarm at the approach of danger." 249 Failure to do so would result in the "liberties of the people" being "subverted." 250 Barbour also specifically expressed concern for the fate of aliens - a concern not necessarily shared by his colleagues ${ }^{251}$ — when he pleaded: "But what good reason could America assign for refusing admittance to strangers, with a country extensive, fertile beyond exception, and uninhabited. Had not the persecuted alien, then, a claim upon us not to be frittered away by the ingenuity of sophistry?" 252 More typical was Del. Foushee's warning that if aliens could be persecuted, citizens soon would be as well. ${ }^{253}$ Though motivated by varying concerns, the Virginia legislature's basic message was nonetheless clear: the Alien and Sedition Acts were dangerous, and ought to be opposed.

\section{Contemporary Reception of the Virginia Resolutions}

The Virginia Resolutions closed with a call for concurrence and cooperation from the sister-states. Though no legislature other than Kentucky's joined Virginia in condemning the Acts, several states responded to Virginia, and the Resolutions were widely discussed in the popular press. Generally, contemporaries interpreted the Virginia Resolutions as strong assertions of state sovereignty. Of these, some read them as endorsing individual state action, while even others implied that they encouraged disunion. This variety of responses in 1798-99 foreshadowed the conflicting interpretations of the $1830 \mathrm{~s}$.

Several states specifically rejected what they right perceived as Virginia's challenge to judicial supremacy. Massachusetts denied "the right of state legislatures to denounce the administration of that government to which the people, by a solemn compact, have exclusively committed their national concerns," 254 while Vermont similarly stated that "[i]t belongs not to State Legislatures to decide on the constitutionality of laws made by the general government; this power being exclusively vested in the judiciary courts of the Union." 255

Not only opponents of the Resolutions questioned the competence of state legislatures, however. In responding to both sets of Resolutions, New Jersey House

249 Barbour, In the House of Delegates, Thursday, December 20, 1798, in RANDOLPH's REPORT 53 at 55.

250 Id. at 70. The legislature's explanatory "Address of the General Assembly to the People of the Commonwealth of Virginia," issued in January 1799, also emphasized the state's warning role. Address of the General Assembly to the People of the Commonwealth of Virginia, in Woods, supra note 43, at 151.

251 Del. Mercer was clear, for example, that the Virginia Resolutions were meant to protect the Constitution, not to defend aliens. Mercer supra note 227 at 49.

252 Barbour, supra note 249 at 68.

253 Id. at 77. The Kentucky Resolutions themselves also directly embodied this sentiment. They warned that "the friendless alien has been selected as the safest subject of a first experiment; but the citizen will soon follow, or rather has already followed." The Kentucky Resolutions supra note 104 at 166.

254 The Senate of the Commonwealth of Massachusetts, Massachusetts to Virginia, in DOCUMENTS 18 at 18-20.

255 The House of Representatives of the State of Vermont, Vermont to Virginia, October 30, 1799, in Documents 25 at 25. 
Republicans, for example, requested that Congress call a convention to decide the constitutionality of the Acts. Though these Republicans rejected the Federalist argument that "the Supreme Court...is the final arbiter of differences between the federal government and the states," they also rejected the contention that "each state may judge for itself." 256 New York House Republicans also expressed concern at both Resolutions' seeming endorsement of individual state decisionmaking authority. ${ }^{257}$ Though Madison himself would describe "the right to expunge an unconstitutional federal law" as "collective" rather than "individual," taken together, his and Jefferson's work suggested just such an individual right to some in 1798-99258 - legitimizing the South Carolina nullifiers' claim. Whether or not Calhoun's interpretation of Madison's work was "correct," it was plausible and not unique. ${ }^{259}$

Pennsylvania, meanwhile, seemed more distressed that Virginia dared disagree with federal policy than by the state's particular path of resistance. Pennsylvania

256 Frank Maloy Anderson, Contemporary Opinions of the Virginia and Kentucky Resolutions, 5 Am. Hist. Rev. 45, 55 (1899).

$257 \quad$ Id. at 56.

258 See e.g. Anderson, supra note 256, at 55. The New Jersey Republican writing under the name "Observor," for example, endorsed the Virginia and Kentucky Resolutions by arguing that "the constitution is a sovereign compact, made between the individual states, as sovereignties, and the U. States collectively." If, he warned, the "states, individually, have no right to judge when the constitution is violated by Congress, there is an end to all state sovereignty."

259 Most modern scholars have concluded that Calhoun and the South Carolina nullifiers misinterpreted the ' 98 and acted unconstitutionally — or 'heretically' — in nullifying the tariff. To a significant degree, one's assessment of South Carolina's actions depends on one's understanding of the Resolutions. In their influential article, "The Virginia and Kentucky Resolutions: An Episode in Jefferson's and Madison's Defense of Civil Liberties," Adrienne Koch and Harry Ammon claimed that Jefferson and Madison promoted states' rights "as a practical means to protect the civil rights of living person." Koch \& Ammon, supra note 148 , at 146. In sum, they argued, "[h]owever interesting these famous Resolutions may be for the constitutional doctrine they contain, they were intended primarily as a defense, practical and spirited, of civil liberties." Id. at 174. Others, however, such as contemporary Calhoun scholar Clyde Wilson, have scoffed at the idea that Jefferson and Madison were not primarily motivated by a concern for states' rights. Wilson decries the scholars who "invented a self-flattering fable" which teaches that "Jefferson and Madison... really did not care about States' right. They were merely anticipating the great tradition of the American Civil Liberties Union." Wilson, supra note 44, at 2. "The Sedition Act," Wilson has offered as an explanatory note, "was not just an invasion of individual rights; it was an illegal invasion of a sphere that the people had left to the States." Id. In regards to the debate about Madison and Jefferson's intentions, the general implication seems to be that if Koch and Ammon are correct, and Madison and Jefferson indeed subordinated state sovereignty to personal liberties, than Calhoun is a 'heretic,' rather than their legitimate heir. If, however Wilson is correct, than Calhoun "revived and perfected" the Resolutions. Bassani, at supra note 143. An alternative option, however, is that both the personal liberties argument advanced by Koch and Ammon and the state sovereignty argument advanced by Wilson are partially correct. If we recognize Madison and the Virginia Resolution as belonging primarily to one tradition and Jefferson and the Kentucky Resolutions to another, than we can better understand how and why late-in-life Madison and the South Carolina nullifiers came to interpret the same documents and events so differently. And, we can better understand how modern movements, such as sanctuary movement, compare to other challenges to federal authority. 
responded to Virginia with a mere sentence, criticizing the Resolutions as "calculated to excite unwarrantable discontents, and to destroy the very existence of our government." ${ }^{260}$ Notably, two days before, the Pennsylvania legislature had issued a multi-paragraph denunciation of the Kentucky Resolutions which defended the Alien and Sedition Acts and denied that states possessed the right to declare any federal act to be "not law" but "void, and of no effect." 261 Pennsylvania's responses suggest that it, unlike the New Jersey Republicans, declined to interpret the Virginia Resolutions as advocating the invalidation of federal law by a single state; ${ }^{262}$ nevertheless, it disapproved. Similarly, for Federalist newspaper edit John Fenno, "it was the possibility of resistance to the federal government rather than the cause of that opposition or the proposed method of resistance that... seemed the important side of the affair." 263

\section{Applications of the Virginia Resolutions}

Despite the uproar caused by the '98 Resolutions, Federalist and Republican legislatures alike resorted to resolution-writing during the early $1800 \mathrm{~s}$. Many of these resolves echoed the Virginia Resolutions - and to a lesser degree the Kentucky Resolutions. Though erstwhile opponents' reimagining of resolution-writing as legitimate protest rather than subversive opposition may have been prompted in part by partisan convenience, the style of these resolves also suggests a genuine desire on the part of legislatures to balance effective local activism with deference to federal authority. Tellingly, while occasional mention was made of Madison or interposition, the word "nullification" appears to have been seldom used after 1799. ${ }^{264}$ On the whole, these "inter-crisis" resolves - those written between the Alien and Sedition crisis of 1798 and the Nullification Crisis of the 1830s - aligned more closely with the Madisonian tradition of interposition than the Jeffersonian tradition of nullification. ${ }^{265}$ These resolves cast state opposition as a means of maintaining checks and balances and personal liberties. Despite the initial conflation of Virginia

260 The House of Representatives of the Commonwealth of Pennsylvania, Resolutions of the House of Representatives of Pennsylvania to Virginia, March 11, 1799, in Documents 22 at 22.

261 See Pennsylvania supra note 170.

262 Other states, however, appeared to interpret both sets of Resolutions as one and the same and responded to them together. See New York and New Hampshire supra notes 170-174.

263 Anderson, supra note 256, at 48.

264 I was unable to find a single instance of the word's use in all the resolves included in Herman V. Ames' multi-volume collection, State Documents on Federal Relations (herein DOCUMENTS).

265 Law professor Christian Fritz's description of interposition aptly describes the approach taken by many state legislatures during this inter-crisis period. According to Fritz: "Interposition sought reversal of national laws that some thought unconstitutional or simply wrong-headed. It involved many potential instruments and actions to maintain the Constitution's health. It could involve individual citizens or groups of citizens. It might also involve the state legislatures, not acting as the sovereign but as an instrument of the people to communicate concerns about the national constitution." Christian G. Fritz, Interposition and the Heresy of Nullification: James Madison and the Exercise of Constitutional Sovereign Powers, 41 First PRINCIPLES 1, 2 (2012). 
and Kentucky's positions, the decades that followed highlighted the differences among the Resolutions, and the doctrines they advocated.

An early series of resolves opposing the Embargo Act displayed a basic willingness to challenge the federal government through state legislatures, but underplayed state sovereignty even relative to the Virginia Resolutions; these resolves emphasized the protection of personal liberties, and the maintenance of checks and balances. President Jefferson had signed the embargo-which closed ports and restricted trade - to retaliate against British and French attacks on American ships. ${ }^{266}$ The Secretary of War had also requested governors to deploy their militias to aid in the enforcement of the embargo. ${ }^{267}$ Though it initially enjoyed support, the embargo quickly became unpopular in those states whose economy depended on shipping and trade.

Federalists in the Delaware House drafted resolves calling for a repeal of the embargo in $1809 ;{ }^{268}$ though these followed the same structure as the Kentucky Resolutions, they explicitly rejected "open opposition to the laws," preferring to submit to the laws than "jeopardize the union of the States." 269 That same year, the Federalist Massachusetts House also sent a set of resolves to its Republican governor, condemning his unwillingness to oppose the embargo. ${ }^{270}$ Responding to the governor's claim that the legislature should not criticize the government, the House stated: "We cannot agree with your Honour than in a free country there is any stage at which the constitutionality of an act may no longer be open to discussion or debate." ${ }^{271}$ Nevertheless, the House stopped short of claiming the right of constitutional interpretation for itself, characterizing the right of "deliberation or remonstrance" as belonging to "the citizen." 272 And, rather than appealing to state sovereignty to justify their opposition, they cited an attachment to "balanced government" and "civil liberty."273 Resolves adopted that same year in Rhode Island came closest to emphasizing state sovereignty, but characterized the federal government's overreach as infringing on the people's rights rather than the state's authority. 274

266 Embargo of 1807, Thomas Jefferson Encyclopedia, https://www.monticello.org/site/ research-and-collections/embargo-1807.

267 Ames, Connecticut and the Enforcement Act, in DocumENTs 38 at 38.

268 The resolves remained in draft form, however, as the House and Senate could not agree on a final version. Ames, Delaware and the Embargo, in Documents 36 at 36.

269 The House of Representatives of the State of Connecticut, Delaware Resolves, in DOCUMENTs 36 at $37-38$.

270 The governor, a Republican, supported the embargo contrary to the Federalist legislature's wishes. Ames, The General Court of Massachusetts on the Embargo, in DocumENTs 26 at 26.

271 The House of Representatives of the Commonwealth of Massachusetts, Extract from the Answer of the House, in DocumenTs 29 at 30.

272 Id. at 30-31.

273 Id. at 31.

274 The Rhode Island resolves read, in relevant part: "That to preserve the Union and to support the constitution of the United States, it becomes the duty of this General Assembly, while it is cautious not to infringe upon the constitutional and delegated powers and rights of the General Government, to be vigilant in guarding from usurpations and violations, those powers and rights which the good people of this State have expressly reserved to themselves, and have ever refused to delegate." The State of Rhode Island and Providence Plantations, Report and Resolutions of Rhode Island on the Embargo, in DocumenTs 43, at 44. 
Connecticut's resolves of that same year, along with an address from its governor, John Turnbull, also emphasized the state's role as a "protecting shield between the right and liberty of the people, and the assumed power of the General Government" and directly referenced the "right...to interpose." 275 The state legislature passed resolves the very same day as the governor's speech, praising his decision to "decline[] to designate persons to carry into effect, by the aid of military power, the act of the United States, enforcing the Embargo." 276 The legislature further declared that "the persons holding executive office under this State are restrained by the duties which they owe this State, from affording any official aid or co-operation in the execution of the act aforesaid." ${ }^{277}$ In closing, Connecticut echoed Massachusetts in calling for "alterations in the constitution."278 Connecticut's response, which foreshadowed the anti-commandeering doctrine articulated by the Supreme Court in New York v. United States and extended in Printz, offered an early example of what interposition might look like in practice. ${ }^{279}$

Resolves passed by Pennsylvania and Virginia in 1811 to oppose the renewal of the Bank of the United States, approximated aspects of the '98 Resolutions, but stopped short of adopting strong state-centric positions. Pennsylvania's resolves specifically referred to the "compact" and stated that "the general government... was not constituted the exclusive or final judge of the powers it was to exercise." 280 Tellingly, however, Pennsylvania identified "the people of the United States"

275 Jonathan Turnbull, Speech of Governor Jonathan Turnbull at the Opening of the Special Session of the Legislature, February 23, 1809, in Documents 39 at 40.

276 The General Assembly of the State of Connecticut, Resolutions of the General Assembly, in DOCUMENTS 40 at 41 .

277 Id

$278 \quad I d$. at 42.

279 New York v. United States, 504 U.S. at 142; Printz, 51 U.S. at 898. Wisconsin and other northern states adopted a similar approach in opposing the Fugitive Slave Act. Several states passed "personal liberty laws" in the 1850s which restricted state cooperation with federal officials. Specifically, "[t]hese laws generally prohibited the use of the state's jails for detaining fugitives; provided state officers, under various names, throughout the state, to act as counsel for persons alleged to be fugitives; secured to all such persons the benefits of habeas corpus and trial by jury; required the identity [sic] of the fugitive to be proved by two witnesses; forbade state judges and officers to issue writs or give any assistance to the claimant; and imposed a heavy fine and imprisonment for the crime of forcibly seizing or representing as a slave any free person with intent to reduce him to slavery." As $19^{\text {th }}$ c. historian Alexander Johnston noted in comparing South Carolina and Wisconsin's opposition to federal law: while "the latter absolutely prohibited the execution of the tariff act...the former only impeded the rendition of fugitive slaves;" Johnston thus concluded that Wisconsin's actions were not properly termed "nullification." Tellingly, in a set of resolves criticizing the Supreme Court's invalidation of its personal liberty laws, the Wisconsin legislature replaced the word "nullification" with the term "positive defiance" in the hallmark phrase "nullification is the rightful remedy." Later characterizations notwithstanding, the Wisconsinites seem to have been intent on differentiating between themselves and the South Carolinians. Alexander Johnston, 3 CyClopaedia of Political Science, Political Economy, and of the Political History of the United States by THE BeSt AMERICAN AND EuropeAn Authors (New York: Maynard, Merrill, \& Co., John J. Lalor ed., 1899). But see Woods, supra note 43, at 79 (arguing Wisconsin engaged in nullification).

280 The General Assembly of the Commonwealth of Pennsylvania, Resolutions of Pennsylvania Against the Bank, in Documents 53 at 53. 
rather that the states as reserving those powers not delegated in the Constitution. Though the resolve stated that "it rests with the states, and with the people, to apply suitable remedies" when the government "violate[d] the provisions of the constitution," Pennsylvania's proposed course of action-requesting that its Senators and representatives oppose the charter in Congress-recognized that authority ultimately rested with the federal government rather than the state in that matter. ${ }^{281}$

Massachusetts' 1814 Report and Resolutions against the embargo represented a high-point in Madisonian interposition. Not only did the Report and Resolutions use the term "interpose," 282 but they also explicitly (if grudgingly) cited Madison as authority. ${ }^{283}$ In interpreting Madison, Massachusetts expressed a view of states' rights which, unlike the state sovereignty-centric view embraced by South Carolina, prioritized checks and balances and personal liberties. Massachusetts explained its opposition not as much a defense of its own sovereignty, but rather as a defense of its people-explicitly describing interposition as the action by the state on behalf of the people. ${ }^{284}$ The first resolve, for example, stated that the embargo "contains provisions not warranted by the Constitution of the United States, and violating the rights of the People of this Commonwealth Massachusetts;" 285 all further resolves also refer to the injustices done to the people, rather than to the state. ${ }^{286}$ And, while Massachusetts does refer to itself once as the "free, sovereign and independent State of Massachusetts," the report's writers seem most concerned by the federal government's actions' effects on "the people." ${ }^{287}$ In the American system of "concurrent sovereignty," Massachusetts explains, "[t]he sovereignty reserved to the States, was reserved to protect the Citizens from acts of violence by the United States." 288

Most significantly, the report demonstrates that Massachusetts - at least at that time - understood Madison as having encouraged the states to call a convention for the purpose of amending the Constitution, rather than as having recognized a state veto on federal legislation, or some other form of individual state action. Though the Virginia Resolutions did not specifically call for a convention, Madison suggested in his 1799 defense of the Resolutions that "[t]he Article V Convention was a tool of potential state 'interposition' against congressional abuse."289 The report stated: "This"-i.e. inviting other states to a convention- "was the mode proposed by Mr. Madison in answer to the objections made, as to the tendency of

281 Id.

282 The Massachusetts resolves describe the state as "bound to interpose its powers, and wrest from the oppressor his victim." The General Court of the Commonwealth of Massachusetts, The General Court of Massachusetts on the Embargo, February 22, 1814, in Documents 69 at 72 .

283 Though supportive of Madison's "mode" of opposing constitutional infractions, the Massachusetts legislature could not resist reminding the reader that, in the particular instance of the Alien and Sedition Acts, "opposition [was] without any justifiable cause." Id. at 73.

$284 \quad I d$. at 74.

285 Id. at 71.

286 Id. at $74-75$.

287 Id. at 71.

288 Id. at 73.

289 Robert Natelson, James Madison and the Constitution's "Conventions for Proposing Amendments,” in UNION \& StATEs' Rights, supra note 1, at 37. 
the general Government, to usurp upon that of the states." ${ }^{290}$ This interpretation stands in stark contrast to South Carolina's interpretation of the same document; and, while Massachusetts's interpretation can neither prove nor disprove the legitimacy of South Carolina's, it does support Madison's later claim that the Resolutions should be understood as such - as do the many other resolves from that period which stopped well short of South Carolina's position.

\section{Madison, Interposition and the Sanctuary Movement}

Like the inter-Crisis interposers, the sanctuary movement has relied on personal liberties and checks and balances-type arguments. Sanctuary advocates have argued that sanctuary laws protect aliens from "arbitrary prosecutorial action," 291 ensure "fair and equal" access to city services, ${ }^{292}$ ensure the dignity and integrity of families, ${ }^{293}$ and generally promote a culture of welcome and tolerance. ${ }^{294}$ They have also argued that sanctuary policies respect state and local sovereignty and combat federal overreach; however, these appeals to state and local sovereignty have been in service of the underlying personal liberties and checks and balances-promoting goal. ${ }^{295}$

Likewise, anti-commandeering - the sanctuary movement's preferred means of challenging federal immigration policy in court-aims to promote personal liberties and checks and balances, rather than state sovereignty as such. In the landmark New York v. United States, the Supreme Court explained that "[t]he Constitution does not protect the sovereignty of States for the benefit of the States or state governments as abstract political entities, or even for the benefit of the public officials governing the States. To the contrary, the Constitution divides authority between federal and state governments for the protection of individuals. State sovereignty is not just an end in itself: Rather, federalism secures to citizens the liberties that derive from the diffusion of sovereign power." ${ }^{296}$ This is a far cry from the Calhounian or Jeffersonian understanding of state sovereignty as a worthy end in and of itself.

290 Id. Here, the "answer" Massachusetts is referring to is Report of 1800, which Madison wrote as a defense of the Virginia Resolutions.

291 David Post, Let's Call Them 'Constitutional Cities,' Not 'Sanctuary Cities,' Ok?, THE WASHINGTON Post (Mar. 30, 2017), https://www.washingtonpost.com/news/volokhconspiracy/wp/2017/03/30/lets-call-them-constitutional-cities-not-sanctuary-citiesokay/?utm term=.b5b597ab5ed0.

292 Teaching Tolerance Staff, What's a Sanctuary City Anyway?, Teaching Tolerance (February 1, 2017), https://www.tolerance.org/magazine/whats-a-sanctuary-city-anyway.

293 Mollie Reilly, California Turns Itself into a Sanctuary State, The Huffington Post (Oct. 5, 2017), https://www.huffingtonpost.com/entry/california-sanctuary-state us 59ce7423e4b05f005d341453. ("California's local law enforcement cannot be commandeered and used by the Trump Administration to tear families apart.")

294 See Rhea Mahbubani \& Christie Smith, "Being a Sanctuary City is in Our DNA:" San Francisco Mayor Reassures Residents After Trump's White House Win," NBC, (Nov. 10, 2016) https://www.nbcbayarea.com/news/local/Being-a-Sanctuary-City-is-in-Our-DNASan-Francisco-Mayor-Reassures-Residents-After-Trumps-White-House-Win-400728041. $\mathrm{html}$.

295 See e.g. Complaint at 2, San Francisco v. Trump; Complaint at 24, Chicago v. Sessions.

296 New York v. United States, 505 U.S. at 181 (internal citations omitted). 
Sanctuary advocates, like the interposers, have also stopped short of purporting to invalidate federal law, preferring to simply frustrate its application. San Francisco or other localities' refusal to assist federal immigration authorities is more akin to Connecticut's refusal to enforce the embargo than South Carolina's outright prohibition on tariff collection by both state and federal officers. In Connecticut's refusal to enlist its militia to enforce federal law may be seen the seeds of modern anti-commandeering doctrine, which the sanctuary movement has used to justify its non-cooperation with ICE officers. ${ }^{297}$

Nevertheless, important differences remain between the sanctuary movement and Madisonian interposition. In terms of theory, Madison and his successors regularly invoked the "compact." Though Madison and Jefferson's conception of the "compact" differed, both agreed that the federal government was to a certain extent the creation of the sovereign states - a concept which the sanctuary movement has not appealed to, even in its collective, Madisonian form. In terms of practice, interposers, like nullifiers, also typically issued resolves through state legislatures. By contrast, the sanctuary movement has been largely city-based, and has not engaged in widespread state-level resolve-writing-highlighting the movement's disinterest in compact theory. Ultimately, however, the comparison remains more apt — and less damning ${ }^{298}$ — than that between nullification and the sanctuary movement.

\section{CONCLUSION}

Of all the men who could have been dubbed the "spiritual godfather" for the sanctuary city movement, John C. Calhoun is an odd choice indeed. ${ }^{299}$ Madison himself, or perhaps Connecticut governor Jonathan Turnbull would have been better selections. While the sanctuary movement has declined to adopt much of Madison and his intellectual successor's theory and practice, the spirit of the movement nevertheless remains closer to Madison's interposition tradition than to Jefferson or Calhoun's nullification.

Nullification - the idea that a state can invalidate unconstitutional federal laws within its territory - has not been adopted by the sanctuary movement even in spirit, much less in practice. Sanctuary advocates have not primarily challenged the underlying constitutionality of federal immigration regulation; and they have not generally claimed authority to prevent federal officials from independently enforcing the law. Neither have they relied on compact theory, or the agency view of government. Rather, they have simply declined to assist the federal government with immigration enforcement.

It is true that both the sanctuary movement and nullification assume some level of disagreement with federal policy; there would be no need for sanctuary

297 See supra notes $173-75$.

298 Though infrequently discussed in the scholarly literature, interposition has received favorable treatment by some mainstream academics. See e.g. Christian Fritz, Interposition: An Overlooked Tool of American Constitutionalism, in UNION \& STATES' Rights, supra note 1 , at 165 . Nullification, by contrast, is generally regarded with suspicion.

299 In an article for National Review, Victor David Hansen referred to Calhoun as "the spiritual godfather of sanctuary cities." Hansen, supra note 11. 
cities without federal immigration enforcement, and no need for nullification without a perceived constitutional infraction. It is also true that both the sanctuary movement and nullification rely on localities to manifest this disagreement. Yet local disagreement with federal policy does not nullification make. Nullification is a doctrine with a well-documented history, and well-defined political-philosophical underpinnings - neither of which are shared to any significant degree by the modern sanctuary movement.

Why then, in light of all this, has the sanctuary movement been so persistently compared to nullification? Perhaps it is because movement's opponents have been eager to connect it to a so-called "discredited constitutional heresy." If the sanctuary movement is to be credibly discredited, however, a more historically accurate line of attack may be advisable. 